\title{
Do IPO Firms Manage Earnings?
}

\author{
Moustafa Fadl ${ }^{1}$ \\ ${ }^{1}$ Ph.D., CFA, Finance Department, Clark University, Worcester, MA, USA \\ Correspondence: Moustafa Fadl, Finance Department, Clark University, Worcester, MA, USA. Tel: 1-401-374-0992. \\ E-mail: mabuelfadl@Clarku.edu
}

Received: October 1, 2013

Accepted: October 20, 2013

Online Published: October 23, 2013

doi:10.5430/afr.v2n4p81

URL: http://dx.doi.org/10.5430/afr.v2n4p81

\begin{abstract}
IPO literature documents that IPO firms experience a decline in returns after listing. This paper investigates that phenomena and tries to find reasons for it. Earning management studies report that if companies have a high level of discretionary accruals, then those companies engage in earnings management. This paper connects these two literature branches together by using a third part of literature, which is market timing and market efficiency. I built a dummy variable DTIMERS that takes the value of one if the companies time the market and zero if they do not. I ran multiple regression models where Absolute Discretionary Accrual is the dependent variable, with DTIMERS as an independent variable along with other control variables. The evidence shows the IPO companies that time the market engage in earnings management, and that may explain why those companies in the post-listing period achieve significant negative abnormal returns while other IPOs who do not manage earnings achieve significant positive abnormal return in the post-listing period.
\end{abstract}

Keywords: IPO, Cross-Listing, Market timing, Earning management, Discretionary accruals

\section{Introduction}

IPO literature documents that firms who issue IPO experience negative abnormal return soon after the issuance. In addition, cross-listing literature documents that firms who cross-list their shares for the first time in USA experience negative post-listing abnormal return.

The recent IPO literature (Clarke et al., 2002; Mikkelsonet al., 1997) recognizes the negative performance after issuance which is inconsistent with efficient market or rational market hypothesis. Cross-listing literature (Merjos (1963, 1967); Sagner and McConnell (1986)), investigated the price behavior of newly-listed stocks and documented that stocks, on average earn positive abnormal returns before listing and negative abnormal returns over the four to six weeks period immediately following listing

Jensen (1986) argues that agency cost may motivate managers to waste free cash flows. Teoh et al., (1998b) documented that issuers use discretionary accruals to report strong earnings relative to actual cash flows which results in buyers paying too high a price for those earnings, therefore, after the event the stock price goes back to its normal levels and that may explain the negative performance after issuance.

In this paper, I argue that managerial motivation is the reason why some companies after they issue their IPOs achieve either a positive abnormal return or a negative abnormal return, therefore, the broad generalization that firms achieve negative abnormal returns after their IPOs is misplaced because some IPOs firms earn positive abnormal returns after listing. In addition, this paper identifies the relationship that can determine the managerial motives and how it is related to the firms IPOs prospects

I formed portfolios of companies that realize significant negative abnormal returns in the post-listing period of $(11,+50)$ while the U.S market (host market) condition is a positive based on the average $\mathrm{S} \& \mathrm{P}_{500}$ (Note 1$)$ index for the period $(0$, +50 ). In addition, I formed portfolios of firms that realize significant positive abnormal returns in the post-listing period of $(11,+50)$ while the U.S market (host market) condition is a negative based on the average $\mathrm{S} \& \mathrm{P}_{500}$ index for the period $(0,+50)$. I used the discretionary accruals models to test the hypothesis, that managerial motives are the driving factor to post IPOs negative returns or post IPOs positive returns. On one, hand I evaluated the hypothesis that if firms time the market before they cross-list their IPOs, then those firms managers must have a motive of inflating the pre-IPO price for the firms shares, and "therefore", they will also engage in earnings management. On the other hand, if managers do not time the market, then they more than likely not to engage in earnings management. I define that those companies engaging in earnings management have a positive, and significant discretionary accruals while others who are not engaging in earnings management have a negative, and significant discretionary accruals. To conduct the analysis, I created a dummy variable where it is equal to one if companies time the market and zero if they do not. 
I employed the current models used in the literature (Note 2) to estimate discretionary accruals. It is widely recognized that the distributions of daily returns indicate heteroscedasticity and autocorrelation; "therefore" I conducted the research with different estimation techniques to correct for both heteroscedasticity and autocorrelation. In addition, I used parametric and non-parametric tests to confirm the validity of the results.

There are various competing explanations have been provided for this anomaly, but there is still lack of consensuses. Kutsuna et al., (2002) reported that the price reversal after IPOs were either from the position of irrational market expectations or managerial timing hypothesis. According to Jensen and Meckling (1976), managerial bias can affect the timing which managers want to list the company shares.

The evidence presented in this paper finds that companies that time the market achieve significant negative post-IPO abnormal returns, and they have significant positive contributions to discretionary accruals; hence, they engage in earnings management. Moreover, companies that do not time the market achieve significant positive abnormal return in the post-IPO period and they have significant negative contribution to the discretionary accruals; hence they do not engage in earnings management.

This paper contributes to the literature in several ways. First, it challenges the status quo that IPO firms that cross-list will experience negative abnormal returns because the paper proves that there are some companies that achieve positive abnormal returns in post-IPO period. Second, the paper provided a method of determining managerial motives by developing the host market index as a means to distinguish from it managerial motives, as such if the host market is a positive and managers are trying to list their IPO in that opportunity, then that is a reason to believe that the managers motives are market timing and vice versa. Second, this study also proves that managerial motives as proxy by earning management are the main reasons why some firms after their IPO they either obtain negative or positive abnormal returns. Third, this study also proves that managerial motives as proxy by earning management are the main reasons why some firms after their IPO they either obtain negative or positive abnormal returns. Fourth, the study leaves open other research questions such as what is the effect of market timing on the company's prospects.

\section{Literature Review}

Pagano et al., (2002) examines the aggregate trends in foreign listings, and they find that high-growth European firms that grow quickly without significant leveraging tend to cross-list in the U.S. Ball and Shivakumar (2005) documents that companies who wants to list in the U.S. face a higher reporting level due to enhanced market demand and regulatory incentives. Fuerst (1998) Cheung CS, Lee J (1995), report that firms cross-list in a strong regulatory framework to show their high quality. Doidge et al., (2004) documents those foreign firms who enter in the U.S. market are doing so in order to take advantage of their growth opportunities.

According to Ritter (1984b), earnings are a significant factor in determining the early market values of IPO firms. Bruner et al., (2004) suggest that foreign firms with high quality are able to gain access to the U.S. market but if the operating performance does not reflect the perception of high quality they considered those firms IPOs to be consistent with the "window-dressing" concept as mentioned through the work of Teoh et al. (1998) who report that firms adopt discretionary accrual methods to boost their earning, so they look superb for the IPO listing. Nurwati A. and Ahmad-Zaluki (2008) report that there is deterioration in operating performance of IPO companies relative to matching companies following IPOs and that earnings management exists at the time of IPOs due to alteration of pre-IPO accruals. Nurwati A. and Ahmad-Zaluki (2008) documents that lower quality firms are more likely to window-dress. DuCharme, Malatesta, and Sefcik (2004) produce results that support the idea that some firms opportunistically manipulate earnings upward before stock issues. Kahneman et al., (1982) argue that investors are subject to cognitive biases often predict future uncertain events by taking a brief history of information, and when such investors make mistaken beliefs about significant positive accruals that make the market price departs from fundamentals over a period of time. Daniel et al. (1998) report that investors overestimate their knowledge and abilities to build a trading strategy from that information and if they were successful once that will even makes the investors more overconfident about their abilities and such bias he called "self-attribution". According to Daniel et al., 1998 that the self-attribution bias will move the stock price even higher than their intrinsic value. Smith et al., (1997) find that the stock prices of cross-listed firms grow by $8 \%$ at the time of listing on U.S. stock exchanges and decline thereafter. Jain and Kini (1994) report that operating performance for post-listing IPO firms decline relative to their pre-IPO levels. Roosenboom et al., (2003) provides evidence in support of IPO price change and reality of earning management. The IPO studies have shown us that after time has passed a price turnaround is more likely to occur, but there is a considerable variation in the stock performance for those IPOs across firms.

Biddle and Saudagaran (1992) find that the tough listing threshold prevents firms from cross-listing on U.S. exchanges. Dechow and Skinner (2000) and Healy et al., (1999), find that firms manage earnings to get cheaper capital, to meet analysts' projections, to fulfill regulatory thresholds, and to increase stock prices. Bailey, Karolyi, and Salva (2006) find that firms who enter in the United States enjoy high returns. 
M. Mezhoud and A. Aoubaker (2012) report that there is a window of 30 days trading period where price adjust and there is an underperformance of IPOs for three years after they list. Lang, Lins and Miller (2003) report that firms who cross-list on U.S. exchanges experience higher valuation. Reese and Weisbach (2001) and Lang et al., (2006) suggest that financial statements reporting that is not clear creates an opportunity for foreign firms to manage earnings. Anand et al., (2006) note the first proxy for a company's earnings quality is the common factor identified by factor analysis performed on three measures of earnings quality commonly reported in the literature: accruals quality, earnings variability, and the absolute value of abnormal accruals. Dechow, Sloan, and Sweeney (1996) report there is strong and robust evidence that the level of accruals is a negative cross-sectional predictor of abnormal stock returns. Desai, Rajgopal, and Venkatachalam (2004), and Pincus, Rajgopal, and Venkatachalam (2007) both document that cash flows is an effective cross-sectional predictor of returns. Ndubizu (2007) reports that cross-listed firms have significant return on assets (ROA), cash flows, and working capital accruals that peak in the listing period, and decrease in subsequent years. Hence, he concluded that cross-listed firms could be either timing their listings or managing earnings. Lee (1991) and Rothman (1995) report a positive market reaction at the time of cross-listing. Hirshleifer, Hou, Teoh, and Zhang (2004) find that net operating assets scaled by lagged total assets are a strong negative predictor of future stock returns. DuCharme, Malatesta, and Sefcik (2004) argue that some firms manipulate earnings before stock offerings. Ball and Shivakumar (2006) and Jo and Kim (2007) have produced recent studies suggesting that firms issuing equity can raise their stock price briefly via earnings management prior to the offering. Teoh, Welch, and Wong (1998) find that firms report increasing discretionary accruals before seasoned equity offerings and that post-listing performance is negatively related to earnings management. Capital-raising events are a suitable motivation for earnings management, and Teoh et al., (1998a, 1998b); and Erickson and Wang (1999) document that discretionary accruals are used to inflate earnings prior listing.

Carow, Cox, and Roden (2006) provide evidence that manager influence the terms of their firms offer price for the IPO shares. Healy and Wahlen (1999) conclude that some managers inflate reported earnings before public equity offers in order to change investors' expectations of future performance and increase the offer price. Ljungqvist and Wilhelm (2003) find that the percentage of shares allocated to friends and family in internet IPOs is positively related to underpricing, which suggests managerial control in the process. Lowry and Murphy (2006) consider executive stock options issued at the IPO bid price and find no correlation between the options and underpricing and agree that claims of managerial rent-seeking in the literature may be overstated. So one can conclude that the literature is divided on why IPOs net negative or declining returns after they list.

\section{Sample and Data}

I conducted the research from 2002 to 2009 because this period has the most recent data available and to take advantage of changing market conditions in the U.S. market (host market). The study uses foreign companies that chose to list their IPOs in the U.S. market. The sample included only IPO for foreign companies in order to assess the impact of IPOs and cross-listing event on post-listing returns. Table 1 shows the list of countries used in the sample, their firms daily average return, and the corresponding host market index return $\left(\mathrm{S} \& \mathrm{P}_{500}\right)$. Table 1 show that the sample has 2,508 observations with a 0.0041 average daily return for the IPOs companies that listed in the US market.

Table 1.

\begin{tabular}{ccccccc}
\hline & \multicolumn{3}{c}{ Daily Domestic Return } & \multicolumn{3}{c}{ Host Market Index Return } \\
\cline { 2 - 7 } & Mean & Std Dev & \# Obs & Mean & Std Dev & \# Obs \\
\hline Country & & & & & & \\
London & .00016 & .01824 & 30 & .30233 & .95781 & 30 \\
Bermuda & .00064 & .03296 & 180 & .09242 & .78735 & 198 \\
Canada & .00354 & .03269 & 60 & -.0440 & 1.0345 & 60 \\
India & .01065 & .04430 & 30 & -.0717 & .38237 & 30 \\
Mexico & .00403 & .04258 & 90 & .21283 & 1.0388 & 120 \\
Israel & .00337 & .04631 & 180 & -.0418 & .74243 & 180 \\
KOREA & -.0025 & .02392 & 60 & .08900 & .49604 & 60 \\
TAIWAN & .00026 & .03203 & 60 & .06000 & .44788 & 60 \\
China & .00719 & .12402 & 1,140 & .08559 & .74199 & 1,200 \\
Netherland & .00781 & .03467 & 60 & -.0353 & .52551 & 60 \\
Brazil & -.0014 & .01522 & 60 & -.0393 & .52491 & 60 \\
Greece & -.0031 & .02561 & 300 & .11380 & .73073 & 300 \\
Argentina & .00797 & .03603 & 30 & -.0363 & .53614 & 30 \\
SPAIN & .01065 & .03637 & 30 & -.0373 & .63610 & 30 \\
COLOMBIA & -.0104 & .06506 & 30 & .34733 & 1.6781 & 30 \\
Total & .00401 & .09015 & 2,508 & .08191 & .78805 & 2,508 \\
\hline
\end{tabular}


I collected data for non-U.S. companies listing in the U.S. exchange market along with the listing dates from the NYSE and the NASDAQ fact book and then verified those dates from the Center for Research and Security Prices (CRSP). Moreover, I checked the Thompson Reuter's database to verify the foreign country and the listing date. I collected post-listing daily prices from the Thomson Reuters database and CRSP daily stock prices tape to confirm it. I used the closing price of the stock at each day and matched the daily price with the daily price of the market index. The accumulation of daily stock prices and daily market index method will help determine the daily stock return and the daily market index return, respectively.

IPO literature produced convincing evidence that the listing date is the event date as documented by Lau at el. (1994) who finds that price reactions are most likely to occur on the first trading day and not on either the cross-listing application or compliance dates. Moreover, Valero at el. (2009) analyzed the stocks' behavior around the listing day rather than the announcement dates, due to difficulties in identifying the exact announcement dates. Therefore, the event date will be the actual IPO listing date.

The sample began with 300 non-U.S. companies that cross-listed their IPOs in the United States either on the NYSE or NASDAQ during the period from 2002 to 2009. The criteria for the pre-listing period are such that the assessment period would be from -545 to -51 days before the event date (listing date), and the post-listing period to be at least 365 days after the listing date. I chose long pre-listing days to have an economically powerful analysis, and for the post-listing period range, I wanted to assure the continuity of the stocks after they do cross-list in order to obtain valid inferences drawn from the analyses. The sample resulted in 89 non-U.S. companies from fifteen different countries. To have an estimate of the normal returns for IPOs firms, I used a matched portfolio of companies as suggested by Brav and Gompers (1997), Carter, Dark, and Singh (1998), Gompers and Lerner (2005).

\section{Hypothesis Development}

I built on the findings of M. Fadl (2013) that IPO companies who achieve negative abnormal returns after they list are the companies who time the market. I started with forming portfolios of companies that demonstrate market timing behavior and portfolios of companies that do not. According to S. Agarwal, C. Liu, S.G. Rhee (2008), investors have either a high demand or a low demand for certain IPOs offerings, as such, when investors demand is high for some IPOs offerings then those IPOs achieve an initial positive returns but negative in long run and vice versa

I built on those ideas by giving a reason of why investors demand are high for certain IPOs offerings and low in another, as such, when investors know that some companies are timing the market, then they are most likely will manage earnings so investors demands will be low in that instance and vice versa. Table 2 shows that some IPOs companies who cross-list while the U.S. market (host market) condition is a positive (based on the average $\mathrm{S}_{5} \mathrm{P}_{500}$ index return in the period $(0,+50)$, achieve significant negative abnormal returns $(-26.19 \%)$ after their IPOs cross-list, particularly in the period $(11,+50)$. The study concludes that since the host market condition is a positive, and the post-listing abnormal return for those companies is a negative then these companies must be timing the market. I reached that conclusion, because why these companies achieved negative post-listing abnormal returns while the U.S. market (host market) is favorable while these companies are supposed to be listing their IPOs because they are expecting positive growth opportunities,. It follows that the market participants have concluded that these companies time the market and discount these companies price after the IPO, which supports hypothesis $\mathrm{H}_{1 \mathrm{~A}}$ : Some companies time the market

Table 2. $\mathrm{H}_{1 \mathrm{~A}}$ : Some companies time the market

\begin{tabular}{|c|c|c|c|c|c|c|c|c|c|}
\hline \multicolumn{10}{|c|}{ Market Model, $+\mathbf{S} \& \mathbf{P}_{500}(0,+50)$} \\
\hline Days & $\begin{array}{l}\mathbf{N} \\
+:-\end{array}$ & $\begin{array}{l}\text { Mean Cumulative } \\
\text { Abnormal Return/ } \\
\text { PWCAAR/ } \\
\text { Median }\end{array}$ & $\begin{array}{l}\text { Patell } \\
\mathrm{Z}\end{array}$ & $\begin{array}{l}\text { StdCsect } \\
\text { Z }\end{array}$ & $\begin{array}{l}\text { CSectErr } \\
t\end{array}$ & $\begin{array}{l}\text { Generalized } \\
\text { Sign } Z\end{array}$ & $\begin{array}{l}\text { Rank Test } \\
\mathrm{Z}\end{array}$ & $\begin{array}{l}\text { Signed } \\
\text { Rank }\end{array}$ & $\begin{array}{l}\text { Skewness } \\
\text { Corrected } \\
\text { T1 }\end{array}$ \\
\hline$(-1,+1)$ & $\begin{array}{l}20 \\
10: 10\end{array}$ & $\begin{array}{l}1.33 \% \\
1.96 \% \\
-0.30 \%\end{array}$ & $\begin{array}{l}7.095 \\
(<.001)\end{array}$ & $\begin{array}{l}0.553 \\
(0.290)\end{array}$ & $\begin{array}{l}0.470 \\
(0.319)\end{array}$ & $\begin{array}{l}-0.342 \\
(0.366)\end{array}$ & $\begin{array}{l}-0.226 \\
(0.411)\end{array}$ & $\begin{array}{l}6.000 \\
(0.420)\end{array}$ & $\begin{array}{l}0.498 \\
(0.309)\end{array}$ \\
\hline$(-3,+3)$ & $\begin{array}{l}20 \\
9: 11\end{array}$ & $\begin{array}{l}-0.58 \% \\
0.39 \% \\
-0.40 \%\end{array}$ & $\begin{array}{l}0.328 \\
(0.372)\end{array}$ & $\begin{array}{l}0.037 \\
(0.485)\end{array}$ & $\begin{array}{l}-0.181 \\
(0.428)\end{array}$ & $\begin{array}{l}-0.791 \\
(0.214)\end{array}$ & $\begin{array}{l}-2.130 \\
(0.017)\end{array}$ & $\begin{array}{l}-13.000 \\
(0.324)\end{array}$ & $\begin{array}{l}-0.180 \\
(0.429)\end{array}$ \\
\hline$(+1,+20)$ & $\begin{array}{l}20 \\
1: 19<<<\end{array}$ & $\begin{array}{l}-14.60 \% \\
-14.13 \% \\
-12.78 \%\end{array}$ & $\begin{array}{l}-22.911 \\
(<.001)\end{array}$ & $\begin{array}{l}-4.271 \\
(<.001)\end{array}$ & $\begin{array}{l}-3.770 \\
(<.001)\end{array}$ & $\begin{array}{l}-4.379 \\
(<.001)\end{array}$ & $\begin{array}{l}-6.477 \\
(<.001)\end{array}$ & $\begin{array}{l}-95.000 \\
(<.001)\end{array}$ & $\begin{array}{l}-5.429 \\
(<.001)\end{array}$ \\
\hline$(0,+50)$ & $\begin{array}{l}20 \\
2: 18<<<\end{array}$ & $\begin{array}{l}-34.00 \% \\
-35.09 \% \\
-40.50 \%\end{array}$ & $\begin{array}{l}-33.227 \\
(<.001)\end{array}$ & $\begin{array}{l}-5.504 \\
(<.001)\end{array}$ & $\begin{array}{l}-4.890 \\
(<.001)\end{array}$ & $\begin{array}{l}-3.931 \\
(<.001)\end{array}$ & $\begin{array}{l}-8.886 \\
(<.001)\end{array}$ & $\begin{array}{l}-97.000 \\
(<.001)\end{array}$ & $\begin{array}{l}-6.512 \\
(<.001)\end{array}$ \\
\hline$(+11,+50)$ & $\begin{array}{l}20 \\
5: 15<<\end{array}$ & $\begin{array}{l}-26.19 \% \\
-28.33 \% \\
-31.69 \%\end{array}$ & $\begin{array}{l}-30.461 \\
(<.001)\end{array}$ & $\begin{array}{l}-4.458 \\
(<.001)\end{array}$ & $\begin{array}{l}-4.552 \\
(<.001)\end{array}$ & $\begin{array}{l}-2.585 \\
(0.005)\end{array}$ & $\begin{array}{l}-6.940 \\
(<.001)\end{array}$ & $\begin{array}{l}-87.000 \\
(<.001)\end{array}$ & $\begin{array}{l}-4.239 \\
(<.001)\end{array}$ \\
\hline
\end{tabular}

P-values are in parentheses. The symbols $(,<,<<,<<<$ or $),>,>>,>>>$ show the direction and generic one-tail significance of the generalized sign test at the $0.10,0.05,0.01$ and 0.001 levels, respectively. 
Further, according to Table 3, some companies IPOs cross-list while the host market condition is a negative (based on the average $\mathrm{S} \& \mathrm{P}_{500}$ index return in the period $(0,+50)$, and yet they achieve significant positive abnormal returns $(17.54 \%)$ after they cross-list, particularly in the period $(11,+50)$. The study concludes that since the host market condition is a negative and the post-listing abnormal return is a positive then there is no post-listing anomaly. Since that the host market condition cannot explain the positive Cumulative average Abnormal Returns (CAAR) for those companies then these companies do not time the market because they cannot be timing a market that is negative "which supports hypothesis" $\mathrm{H}_{1 \mathrm{~B}}$ : Some companies do not time the market.

Table 3. $\mathrm{H}_{1 \mathrm{~B}}$ : Some companies do not time the market

\begin{tabular}{|c|c|c|c|c|c|c|c|c|c|}
\hline \multicolumn{10}{|c|}{ Market Model, $-\mathbf{S} \& P_{500}(0,+50)$} \\
\hline Days & $\begin{array}{l}\mathbf{N} \\
+:-\end{array}$ & $\begin{array}{l}\text { Mean Cumulative } \\
\text { Abnormal Return } \\
\text { /PWCAAR } \\
\text { /Median }\end{array}$ & $\begin{array}{l}\text { Patell } \\
\text { Z }\end{array}$ & $\begin{array}{l}\text { StdCsect } \\
\text { Z }\end{array}$ & $\begin{array}{l}\text { CSectErr } \\
\mathbf{t}\end{array}$ & $\begin{array}{l}\text { Generalized } \\
\text { Sign Z }\end{array}$ & $\begin{array}{l}\text { Rank Test } \\
\mathrm{Z}\end{array}$ & $\begin{array}{l}\text { Signed } \\
\text { Rank }\end{array}$ & $\begin{array}{l}\text { Skewness } \\
\text { Corrected } \\
\text { T1 }\end{array}$ \\
\hline$(-1,+1)$ & $\begin{array}{l}13 \\
11: 2>\end{array}$ & $\begin{array}{l}23.32 \% \\
25.36 \% \\
22.78 \%\end{array}$ & $\begin{array}{l}83.905 \\
(<.001)\end{array}$ & $\begin{array}{l}4.486 \\
(<.001)\end{array}$ & $\begin{array}{l}4.329 \\
(<.001)\end{array}$ & $\begin{array}{l}2.303 \\
(0.011)\end{array}$ & $\begin{array}{l}2.867 \\
(0.002)\end{array}$ & $\begin{array}{l}41.500 \\
(<.001)\end{array}$ & $\begin{array}{l}5.637 \\
(<.001)\end{array}$ \\
\hline$(-3,+3)$ & $\begin{array}{l}13 \\
11: 2>\end{array}$ & $\begin{array}{l}24.35 \% \\
26.21 \% \\
19.63 \%\end{array}$ & $\begin{array}{l}56.514 \\
(<.001)\end{array}$ & $\begin{array}{l}3.810 \\
(<.001)\end{array}$ & $\begin{array}{l}3.443 \\
(<.001)\end{array}$ & $\begin{array}{l}2.303 \\
(0.011)\end{array}$ & $\begin{array}{l}0.089 \\
(0.465)\end{array}$ & $\begin{array}{l}40.500 \\
(0.001)\end{array}$ & $\begin{array}{l}5.061 \\
(<.001)\end{array}$ \\
\hline$(+1,+20)$ & $\begin{array}{l}13 \\
10: 3>\end{array}$ & $\begin{array}{l}32.52 \% \\
34.35 \% \\
21.62 \%\end{array}$ & $\begin{array}{l}43.398 \\
(<.001)\end{array}$ & $\begin{array}{l}3.532 \\
(<.001)\end{array}$ & $\begin{array}{l}3.378 \\
(<.001)\end{array}$ & $\begin{array}{l}1.747 \\
(0.040)\end{array}$ & $\begin{array}{l}1.731 \\
(0.042)\end{array}$ & $\begin{array}{l}39.500 \\
(0.002)\end{array}$ & $\begin{array}{l}4.889 \\
(<.001)\end{array}$ \\
\hline$(0,+50)$ & $\begin{array}{l}13 \\
10: 3>\end{array}$ & $\begin{array}{l}43.71 \% \\
46.16 \% \\
36.94 \%\end{array}$ & $\begin{array}{l}35.560 \\
(<.001)\end{array}$ & $\begin{array}{l}3.536 \\
(<.001)\end{array}$ & $\begin{array}{l}3.479 \\
(<.001)\end{array}$ & $\begin{array}{l}1.747 \\
(0.040)\end{array}$ & $\begin{array}{l}1.469 \\
(0.071)\end{array}$ & $\begin{array}{l}38.500 \\
(0.002)\end{array}$ & $\begin{array}{l}4.287 \\
(<.001)\end{array}$ \\
\hline$(+11,+50)$ & $\begin{array}{l}13 \\
9: 4\end{array}$ & $\begin{array}{l}17.54 \% \\
17.71 \% \\
21.99 \%\end{array}$ & $\begin{array}{l}15.612 \\
(<.001)\end{array}$ & $\begin{array}{l}2.682 \\
(0.004)\end{array}$ & $\begin{array}{l}2.812 \\
(0.002)\end{array}$ & $\begin{array}{l}1.191 \\
(0.117)\end{array}$ & $\begin{array}{l}1.419 \\
(0.078)\end{array}$ & $\begin{array}{l}30.500 \\
(0.016)\end{array}$ & $\begin{array}{l}2.868 \\
(0.002)\end{array}$ \\
\hline
\end{tabular}

P-values are in parentheses. The symbols $(,<,<<,<<<$ or $),>,>>,>>>$ show the direction and generic one-tail significance of the generalized sign test at the $0.10,0.05,0.01$ and 0.001 levels, respectively.

Table 4 shows that some companies IPOs who cross-list while the host market condition is a positive (based on the average portfolio matching $(\mathrm{PM})$ index return in the period $(0,+50)$, and yet the result is significant negative abnormal returns $(-18.87 \%)$ after their IPOs cross-list, particularly in the period $(11,+50)$. The study concludes that since the host market condition is a positive and the post-listing abnormal return is a negative (post-listing anomaly), and the host market condition does not explain the anomaly; then those companies time the market, which supports hypothesis $\mathrm{H}_{2 \mathrm{~A}}$ : Some companies time the market

Table 4. $\mathrm{H}_{2 \mathrm{~A}}$ : Some companies time the market

\begin{tabular}{|c|c|c|c|c|c|c|c|c|c|}
\hline \multicolumn{10}{|c|}{ Market Model, +PM $(0,+50)$} \\
\hline Days & $\begin{array}{l}\mathbf{N} \\
+:-\end{array}$ & $\begin{array}{l}\text { Mean Cumulative } \\
\text { Abnormal Return } \\
\text { /PWCAAR/ } \\
\text { Median }\end{array}$ & $\begin{array}{l}\text { Patell } \\
\text { Z }\end{array}$ & $\begin{array}{l}\text { StdCsect } \\
\mathrm{Z}\end{array}$ & $\begin{array}{l}\text { CSectErr } \\
\mathrm{t}\end{array}$ & $\begin{array}{l}\text { Generalized } \\
\text { Sign Z }\end{array}$ & $\begin{array}{l}\text { Rank Test } \\
\mathrm{Z}\end{array}$ & $\begin{array}{l}\text { Signed } \\
\text { Rank }\end{array}$ & $\begin{array}{l}\text { Skewness } \\
\text { Corrected } \\
\text { T1 }\end{array}$ \\
\hline$(-1,+1)$ & $\begin{array}{l}20 \\
12: 8\end{array}$ & $\begin{array}{l}-0.22 \% \\
-0.15 \% \\
0.30 \%\end{array}$ & $\begin{array}{l}-0.926 \\
(0.177)\end{array}$ & $\begin{array}{l}-0.054 \\
(0.479)\end{array}$ & $\begin{array}{l}-0.116 \\
(0.454)\end{array}$ & $\begin{array}{l}0.651 \\
(0.257)\end{array}$ & $\begin{array}{l}1.270 \\
(0.102)\end{array}$ & $\begin{array}{l}9.000 \\
(0.375)\end{array}$ & $\begin{array}{l}-0.116 \\
(0.454)\end{array}$ \\
\hline$(-3,+3)$ & $\begin{array}{l}20 \\
12: 8\end{array}$ & $\begin{array}{l}-1.50 \% \\
-1.39 \% \\
0.65 \%\end{array}$ & $\begin{array}{l}-6.457 \\
(<.001)\end{array}$ & $\begin{array}{l}-0.521 \\
(0.301)\end{array}$ & $\begin{array}{l}-0.713 \\
(0.238)\end{array}$ & $\begin{array}{l}0.651 \\
(0.257)\end{array}$ & $\begin{array}{l}-0.541 \\
(0.294)\end{array}$ & $\begin{array}{l}-1.000 \\
(0.493)\end{array}$ & $\begin{array}{l}-0.748 \\
(0.227)\end{array}$ \\
\hline$(+1,+20)$ & $\begin{array}{l}20 \\
5: 15<<\end{array}$ & $\begin{array}{l}-7.97 \% \\
-9.60 \% \\
-6.96 \%\end{array}$ & $\begin{array}{l}-27.162 \\
(<.001)\end{array}$ & $\begin{array}{l}-2.856 \\
(0.002)\end{array}$ & $\begin{array}{l}-3.017 \\
(0.001)\end{array}$ & $\begin{array}{l}-2.484 \\
(0.007)\end{array}$ & $\begin{array}{l}-4.721 \\
(<.001)\end{array}$ & $\begin{array}{l}-67.000 \\
(0.005)\end{array}$ & $\begin{array}{l}-3.064 \\
(0.001)\end{array}$ \\
\hline$(0,+50)$ & $\begin{array}{l}20 \\
1: 19<<<\end{array}$ & $\begin{array}{l}-24.09 \% \\
-29.60 \% \\
-16.48 \%\end{array}$ & $\begin{array}{l}-50.607 \\
(<.001)\end{array}$ & $\begin{array}{l}-4.820 \\
(<.001)\end{array}$ & $\begin{array}{l}-4.791 \\
(<.001)\end{array}$ & $\begin{array}{l}-4.276 \\
(<.001)\end{array}$ & $\begin{array}{l}-7.115 \\
(<.001)\end{array}$ & $\begin{array}{l}-103.00 \\
(<.001)\end{array}$ & $\begin{array}{l}-7.899 \\
(<.001)\end{array}$ \\
\hline$(+11,+50)$ & $\begin{array}{l}20 \\
2: 18<<<\end{array}$ & $\begin{array}{l}-18.87 \% \\
-23.56 \% \\
-13.93 \%\end{array}$ & $\begin{array}{l}-45.943 \\
(<.001)\end{array}$ & $\begin{array}{l}-4.321 \\
(<.001)\end{array}$ & $\begin{array}{l}-4.354 \\
(<.001)\end{array}$ & $\begin{array}{l}-3.828 \\
(<.001)\end{array}$ & $\begin{array}{l}-5.956 \\
(<.001)\end{array}$ & $\begin{array}{l}-95.000 \\
(<.001)\end{array}$ & $\begin{array}{l}-5.946 \\
(<.001)\end{array}$ \\
\hline
\end{tabular}

P-values are in parentheses. The symbols $(,<,<<,<<<$ or $),>,>>,>>>$ show the direction and generic one-tail significance of the generalized sign test at the $0.10,0.05,0.01$ and 0.001 levels, respectively.

Further, according to Table 5, some companies IPOs cross-list while the host market condition is a negative (based on the average PM index return in the period $(0,+50)$, and yet they achieve significant positive abnormal returns $(13.58 \%)$ 
after they cross-list, particularly in the period $(11,+50)$. The study concludes that since the host market condition is a negative and the post-listing abnormal return is a positive then there is no post-listing anomaly. Since that, the host market condition cannot explain the positive CAAR for those companies; then these companies do not time the market because they cannot be timing a market that is negative. $\mathrm{H}_{2 \mathrm{~B}}$ : Some companies do not time the market

Table 5. $\mathrm{H}_{2 \mathrm{~B}}$ : Some companies do not time the market

\begin{tabular}{|c|c|c|c|c|c|c|c|c|c|}
\hline \multicolumn{10}{|c|}{ Market Model, -PM(0,+50) } \\
\hline Days & $\begin{array}{l}\mathbf{N} \\
+:-\end{array}$ & $\begin{array}{l}\text { Mean Cumulative } \\
\text { Abnormal Return } \\
\text { /PWCAAR } \\
\text { /Median }\end{array}$ & $\begin{array}{l}\text { Patell } \\
\mathrm{Z}\end{array}$ & $\begin{array}{l}\text { StdCsect } \\
\text { Z }\end{array}$ & $\begin{array}{l}\text { CSectErr } \\
\mathrm{t}\end{array}$ & $\begin{array}{l}\text { Generalized } \\
\text { Sign Z }\end{array}$ & $\begin{array}{l}\text { Rank Test } \\
\mathrm{Z}\end{array}$ & $\begin{array}{l}\text { Signed } \\
\text { Rank }\end{array}$ & $\begin{array}{l}\text { Skewness } \\
\text { Corrected } \\
\text { T1 }\end{array}$ \\
\hline$(-1,+1)$ & $\begin{array}{l}13 \\
11: 2>\end{array}$ & $\begin{array}{l}23.12 \% \\
25.39 \% \\
22.56 \%\end{array}$ & $\begin{array}{l}159.971 \\
(<.001)\end{array}$ & $\begin{array}{l}4.379 \\
(<.001)\end{array}$ & $\begin{array}{l}4.340 \\
(<.001)\end{array}$ & $\begin{array}{l}2.294 \\
(0.011)\end{array}$ & $\begin{array}{l}2.029 \\
(0.021)\end{array}$ & $\begin{array}{l}41.500 \\
(<.001)\end{array}$ & $\begin{array}{l}5.542 \\
(<.001)\end{array}$ \\
\hline$(-3,+3)$ & $\begin{array}{l}13 \\
10: 3>\end{array}$ & $\begin{array}{l}24.35 \% \\
26.71 \% \\
19.98 \%\end{array}$ & $\begin{array}{l}107.654 \\
(<.001)\end{array}$ & $\begin{array}{l}3.851 \\
(<.001)\end{array}$ & $\begin{array}{l}3.507 \\
(<.001)\end{array}$ & $\begin{array}{l}1.738 \\
(0.041)\end{array}$ & $\begin{array}{l}-0.514 \\
(0.304)\end{array}$ & $\begin{array}{l}39.500 \\
(0.002)\end{array}$ & $\begin{array}{l}5.086 \\
(<.001)\end{array}$ \\
\hline$(+1,+20)$ & $\begin{array}{l}13 \\
10: 3>\end{array}$ & $\begin{array}{l}29.90 \% \\
32.68 \% \\
19.48 \%\end{array}$ & $\begin{array}{l}76.601 \\
(<.001)\end{array}$ & $\begin{array}{l}3.378 \\
(<.001)\end{array}$ & $\begin{array}{l}3.296 \\
(<.001)\end{array}$ & $\begin{array}{l}1.738 \\
(0.041)\end{array}$ & $\begin{array}{l}1.358 \\
(0.087)\end{array}$ & $\begin{array}{l}39.500 \\
(0.002)\end{array}$ & $\begin{array}{l}4.688 \\
(<.001)\end{array}$ \\
\hline$(0,+50)$ & $\begin{array}{l}13 \\
10: 3>\end{array}$ & $\begin{array}{l}39.43 \% \\
44.08 \% \\
35.60 \%\end{array}$ & $\begin{array}{l}61.392 \\
(<.001)\end{array}$ & $\begin{array}{l}3.378 \\
(<.001)\end{array}$ & $\begin{array}{l}3.346 \\
(<.001)\end{array}$ & $\begin{array}{l}1.738 \\
(0.041)\end{array}$ & $\begin{array}{l}0.703 \\
(0.241)\end{array}$ & $\begin{array}{l}35.500 \\
(0.005)\end{array}$ & $\begin{array}{l}3.990 \\
(<.001)\end{array}$ \\
\hline$(+11,+50)$ & $\begin{array}{l}13 \\
8: 5\end{array}$ & $\begin{array}{l}13.58 \% \\
15.81 \% \\
19.89 \%\end{array}$ & $\begin{array}{l}23.759 \\
(<.001)\end{array}$ & $\begin{array}{l}2.285 \\
(0.011)\end{array}$ & $\begin{array}{l}2.325 \\
(0.010)\end{array}$ & $\begin{array}{l}0.627 \\
(0.265)\end{array}$ & $\begin{array}{l}0.417 \\
(0.338)\end{array}$ & $\begin{array}{l}27.500 \\
(0.029)\end{array}$ & $\begin{array}{l}2.399 \\
(0.008)\end{array}$ \\
\hline
\end{tabular}

P-values are in parentheses. The symbols $(,<,<<,<<<$ or $),>,>>,>>>$ show the direction and generic one-tail significance of the generalized sign test at the $0.10,0.05,0.01$ and 0.001 levels, respectively.

Total accruals are usually defined according to Dechow et al. (1995, p. 203) as the difference between net income $\left(\mathrm{NI}_{\mathrm{i}, \mathrm{t}}\right)$, and cash flow from operations $\left(\mathrm{CFO}_{\mathrm{i}, \mathrm{t}}\right)$.

$$
\text { TOTACC }_{\mathrm{i}, \mathrm{t}}=\mathrm{NI}_{\mathrm{i}, \mathrm{t}}-\mathrm{CFO}_{\mathrm{i}, \mathrm{t}}
$$

Instead of computing total accruals from net income and cash flow from operations, the result can be found using current accruals $\left(\right.$ CURRACC $_{\mathrm{i}, \mathrm{t}}$ ), proxy by the change in working capital (excluding cash), and non-current accrual (NONECURRACC $_{i, t}$ ), proxy by depreciation, depletion, and amortization (Dechow et al., 1995, p. 203). In effect, all other accrual items are ignored.

$$
\text { TOTACC }_{\mathrm{i}, \mathrm{t}}=\text { CURRACC }_{\mathrm{i}, \mathrm{t}}+\text { NONECURRACC }_{\mathrm{i}, \mathrm{t}} \text {. }
$$

I used the second definition (equation 2) of total accruals for my model. The model of Kang and Sivaramakrishnan (1995, p. 358) predicts the balance sheet levels of accounts represented in current accruals, rather than changes in those accounts and includes amortization from the income statement, rather than amortization from the cash flow statement. Accrual measures in all models are typically scaled by total assets from the previous year $\left(\mathrm{TA}_{\mathrm{i}, \mathrm{t}}\right)$.

Jones (1991) uses a discretionary accrual proxy similar to that used by Healy (1985) and includes the change in revenues and the level of property, plant, and equipment as other relevant variables. These two variables are designed to capture non-discretionary accruals that may be available. The Jones and modified-Jones models regress total accruals $\left(T_{O T A C C}, \mathrm{t}\right)$ on change in revenues $\left(\triangle \mathrm{REV}_{\mathrm{i}, \mathrm{t}}\right)$ and change of gross property, plant and equipment $\left(\triangle \mathrm{PPE} \mathrm{i}_{\mathrm{i}, \mathrm{t}}\right)$, deflated by beginning-of-fiscal-year total assets $\left(\mathrm{TA}_{\mathrm{i}, \mathrm{t}-1}\right)$. The discretionary accruals of the Jones model are measured by the residuals of that regression.

$$
\frac{\operatorname{TOTACC}_{i, t}}{\mathrm{TA}_{\mathrm{i}, \mathrm{t}-1}}=\alpha_{0} \frac{1}{\mathrm{TA}_{\mathrm{i}, \mathrm{t}-1}}+\beta_{1 \mathrm{t}} \frac{\Delta \mathrm{REV}_{\mathrm{i}, \mathrm{t}}}{\mathrm{TA}_{\mathrm{i}, \mathrm{t}-1}}+\beta_{2 \mathrm{t}} \frac{\Delta \mathrm{PPE}_{\mathrm{i}, \mathrm{t}}}{\mathrm{TA}_{\mathrm{i}, \mathrm{t}-1}}+\varepsilon_{\mathrm{it}} .
$$

Dechow, Sloan, and Sweeney (1996) show that the original Jones model has little power in cases in which firms manipulate earnings through the misstatement of net accounts receivable. This is because the original Jones model includes the change in revenue as a control for non-discretionary accruals. Dechow et al., (1995), Kothari et al., (2005), 
and Ball and Shivakumar (2006) find that the Jones model of non-discretionary accruals is substantially miss-specified. The model ignores the roles of accruals in reducing noise in earnings (Dechow, 1994) and timely loss recognition. Dechow, Sloan, and Sweeney (1996) report that the modified-Jones model adjusts changes in receivables $\left(\Delta \mathrm{REC}_{\mathrm{i}, \mathrm{t}}\right)$ in order to control for the manipulation of revenues through using credit sales. Concerns with such misspecification led researchers to adopt performance-matching procedures.

$$
\frac{\mathrm{TOTACC}_{\mathrm{i}, \mathrm{t}}}{\mathrm{TA}_{\mathrm{i}, \mathrm{t}-1}}=\alpha_{0 \mathrm{t}} \frac{1}{\mathrm{TA}_{\mathrm{i}, \mathrm{t}-1}}+\beta_{1 \mathrm{t}} \frac{\Delta \mathrm{REV}_{\mathrm{i}, \mathrm{t}}-\Delta \mathrm{REC}_{\mathrm{i}, \mathrm{t}}}{\mathrm{TA} \mathrm{A}_{\mathrm{i}, \mathrm{t}-1}}+\beta_{2 \mathrm{t}} \frac{\Delta \mathrm{PPE}_{\mathrm{i}, \mathrm{t}}}{\mathrm{TA}_{\mathrm{i}, \mathrm{t}-1}}+\varepsilon_{\mathrm{it}} .
$$

Kothari, Leone, and Wasley (2005) propose a technique that entails differencing estimates of discretionary accruals from Jones-type models for analysis firms and control firms matched on industry and ROA. However, their results did not produce any significant differences from not using the matching control firms. McNichols (2002) shows models that do not consider long-term earnings growth are particularly susceptible to misspecification and that accruals are positively related to analysts' forecasts of future growth, even after controlling for growth in the current period. Dechow (1994), Barth et al. (2001), and Dechow and Dichev (2002) suggest that accruals are negatively correlated with contemporaneous operating cash flows and positively correlated with past and future operating cash flows. However, the Jones and modified-Jones models do not take into account the systematic associations between operating cash flows and accruals. Dechow et al., (1995) find that surprising accrual models are likely to overestimate (underestimate) unexpected accruals of firms with high (low) operating cash flows. Consistent with McNichols' (2002) augmentation of the Jones model with cash flows, Dechow and Dichev (2002) note that since the goal of non-discretionary accruals is to correct temporary matching problems with an organization's underlying cash flows, they should be negatively correlated with contemporaneous cash flows and positively correlated with adjacent cash flows. Therefore, they suggest including past, present, and future cash flows (CF) as other relevant variables:

$$
\frac{\mathrm{TOTACC}_{i, t}}{\mathrm{TA}_{\mathrm{i}, \mathrm{t}-1}}=\alpha_{\mathrm{i}} \frac{1}{\mathrm{TA}_{\mathrm{i}, \mathrm{t}-1}}+\beta_{1 \mathrm{i}} \frac{\Delta \mathrm{REV}_{\mathrm{i}, \mathrm{t}}-\Delta \mathrm{REC}_{\mathrm{i}, \mathrm{t}}}{\mathrm{TA}_{\mathrm{i}, \mathrm{t}-1}}+\beta_{2 \mathrm{i}} \frac{\Delta \mathrm{PPE}_{\mathrm{i}, \mathrm{t}}}{\mathrm{TA}_{\mathrm{i}, \mathrm{t}-1}}+\delta_{0 \mathrm{t}} \frac{\mathrm{CF}_{\mathrm{i}, \mathrm{t}-1}}{\mathrm{TA}_{\mathrm{i}, \mathrm{t}-1}}+\delta_{1 \mathrm{t}} \frac{\mathrm{CF}_{\mathrm{i}, \mathrm{t}}}{\mathrm{TA}_{\mathrm{i}, \mathrm{t}-1}}+\frac{\mathrm{CF}_{\mathrm{i}, \mathrm{t}+1}}{\mathrm{TA}_{\mathrm{i}, \mathrm{t}-1}}+\varepsilon_{\mathrm{it}} .
$$

Ball et al., (2005), and Ball and Shivakumar, (2006), controlled for the non-linearity of accruals with respect to CF using the following piece-wise modifications of the Jones model with cash flows where $\mathrm{DCF}_{\mathrm{i}, \mathrm{t}}$ is an indicator variable equal to one if operating $\mathrm{CF}\left(\mathrm{CF}_{\mathrm{i}, \mathrm{t}}\right)$ are negative, and zero otherwise; $\mathrm{D} \Delta \mathrm{CF}_{\mathrm{i}, \mathrm{t}}$ is an indicator variable equal to one if operating cash flow changes $\left(\Delta \mathrm{CF}_{\mathrm{i}, \mathrm{t}}\right)$ are negative, and zero otherwise:

$\frac{\mathrm{TOTACC}_{i, \mathrm{t}}}{\mathrm{TA}_{\mathrm{i}, \mathrm{t}-1}}=\alpha_{\mathrm{i}} \frac{1}{\mathrm{TA}_{\mathrm{i}, \mathrm{t}-1}}+\beta_{1 \mathrm{i}} \frac{\Delta \mathrm{REV}_{\mathrm{i}, \mathrm{t}}-\Delta \mathrm{REC}_{\mathrm{i}, \mathrm{t}}}{\mathrm{TA}_{\mathrm{i}, \mathrm{t}-1}}+\beta_{2 \mathrm{i}} \frac{\Delta \mathrm{PPE}_{\mathrm{i}, \mathrm{t}}}{\mathrm{TA}_{\mathrm{i}, \mathrm{t}-1}}+\delta_{0 \mathrm{t}} \frac{\mathrm{CF}_{\mathrm{i}, \mathrm{t}-1}}{\mathrm{TA}_{\mathrm{i}, \mathrm{t}-1}}+\delta_{1 \mathrm{t}} \frac{\mathrm{CF}_{\mathrm{i}, \mathrm{t}}}{\mathrm{TA}_{\mathrm{i}, \mathrm{t}-1}}+\delta_{2 \mathrm{t}} \frac{\mathrm{CF}_{\mathrm{i}, \mathrm{t}+1}}{\mathrm{TA} \mathrm{A}_{\mathrm{i}, \mathrm{t}-1}}+\delta_{3 \mathrm{t}} \frac{\mathrm{D} \Delta \mathrm{CF}_{\mathrm{i}, \mathrm{t}}}{\mathrm{TA}_{\mathrm{i}, \mathrm{t}-1}}+$ $\delta_{3 \mathrm{t}} \frac{\mathrm{D} \Delta \mathrm{CF} \times \Delta \mathrm{CF}_{\mathrm{i}, \mathrm{t}}}{\mathrm{TA}_{\mathrm{i}, \mathrm{t}-1}}+\varepsilon_{\mathrm{it}}$.

In this study, I investigate whether there is earnings management in IPOs cross-listing companies that time the market and IPOs cross-listing companies that do not. I will use the model developed by Ball et al. (2006).

$$
\begin{aligned}
& \mathbf{H}_{\mathbf{0}} \text { : Companies that time the market exhibit earnings management } \\
& \mathbf{H}_{\boldsymbol{A}} \text { : Companies that do not time the market do not reveal earnings management }
\end{aligned}
$$

\section{Research Method}

I created a dummy variable DTIMERS that takes the value of one when the portfolios of companies are market timers, and takes a value of zero when the portfolios of companies are non-market timers. Then, I used the discretionary accrual estimates from equation 6 as this reflects the most recent research on the best way to estimate discretionary accruals. I used an independent sample t-test to compare the means of a normally distributed interval dependent variable for two different groups (market timers and non-market timers). This t-test is designed to compare means of the same variable between two groups. In my sample, I compare the mean of absolute discretionary accruals (Note 3) (ABS_DISCACCR) of firms that time the market with firms that do not, these firms were selected based on a predetermined rule regarding the host market condition, sign, and the significance of the post-listing abnormal returns. When I use the t-test for comparing independent groups, I also test the hypothesis on equal variance. If I assume that the two samples have the same variance, then the first method, called the pooled variance estimator, is used. Otherwise, when the variances are not assumed to be equal, Satterthwaite method is used. According to Table 6, panel (B), $\operatorname{Pr}>\mathrm{F}$ - this is the two-tailed significance probability - is less than $(<0.05)$, so there is evidence that the variances for the two groups, market timers and non-market timers, are different. Therefore, I will rely on the second method (Satterthwaite variance estimator). According to Table 6, panel (A), since the p-value (0.001) - using the Satterthwaite method of the difference in means for the variable ABS_DISCACCR between the timers and non-timers groups-is less than the pre-specified alpha level (0.05), then the difference in means is statistically significantly different from zero. Therefore, I conclude that there is a significant difference between the means of the two samples. 
Table 6. Difference in Means between Market Timers and Non-market Timers (Parametric)

Panel A

Panel B

\begin{tabular}{llllllll}
\hline Timers & Method & Mean & \multicolumn{2}{c}{ 95\% CL Mean } & \multicolumn{2}{c}{ Std Dev } & 95\% CL Std Dev \\
\hline Non-Timers & & 0.0252 & 0.0248 & 0.0255 & 0.0260 & 0.0258 & 0.0263 \\
Timers & & 0.0591 & 0.0584 & 0.0597 & 0.0569 & 0.0565 & 0.0574 \\
Diff (1-2) & Pooled & -0.0339 & -0.0347 & -0.0331 & 0.0461 & 0.0458 & 0.0464 \\
Diff (1-2) & Satterthwaite & -0.0339 & -0.0346 & -0.0331 & & & \\
\hline
\end{tabular}

\begin{tabular}{lllll}
\hline \multicolumn{5}{c}{ Equality of Variances } \\
\hline Method & Num DF & Den DF & F Value & Pr $>$ F \\
\hline Folded F & 28710 & 22186 & 4.79 & $<.0001$ \\
\hline
\end{tabular}

In addition to using parametric tests, I used non-parametric tests because the daily returns distribution is not normally distributed. The Wilcoxon-Mann-Whitney test is a non-parametric analog to the independent samples' t-test. According to Table 7, panel (A), the results suggest there is a statistically significant difference between the underlying distributions of market timers and the non-market timers $(\mathrm{z}=-81.1443, \mathrm{p}=0.0001)$. The Mann-Whitney and the corresponding Wilcoxon tests are rank sum tests and not median tests.

Table 7. Difference in Means and Medians between Market Timers and Non-market Timers (Non-parametric)

\begin{tabular}{ll}
\hline Panel A: & \\
\hline Wilcoxon two-sample test & \\
Statistic & \\
& \\
Normal approximation & \\
$\mathbf{Z}$ & -81.1443 \\
One-Sided $\operatorname{Pr}<\mathbf{Z}$ & $<.0001$ \\
Two-Sided $\operatorname{Pr}>|\mathbf{Z}|$ & $<.0001$ \\
& \\
t approximation & \\
One-Sided $P r<\mathbf{Z}$ & $<.0001$ \\
Two-Sided $\operatorname{Pr}>|\mathbf{Z}|$ & $<.0001$ \\
$\mathbf{Z}$ includes a continuity correction of 0.5 \\
\hline
\end{tabular}

It is possible, for groups to have different rank sums and yet have similar or nearly identical medians. Therefore, I conducted a difference in median tests between market timers and non-market timers. According to Table 7, panel (B), the results suggest there is a statistically significant difference between the underlying distributions of market timers and the non-market timers $(z=-63.4016, p=0.0001)$.

\begin{tabular}{lc}
\hline \multicolumn{2}{l}{ Panel B: } \\
\hline Median Two-Sample Test \\
\hline Statistic & 7555.000 \\
& 0 \\
$\mathbf{Z}$ & -63.4016 \\
One-Sided Pr $<\mathbf{Z}$ & $<.0001$ \\
Two-Sided Pr $>|Z|$ & $<.0001$ \\
\hline Table 7: Panel C: \\
\hline Median One-Way Analysis \\
\hline Chi-Square & 4019.7657 \\
DF & 1 \\
Pr $>$ Chi-Square & $<.0001$ \\
\hline
\end{tabular}


After I established that there was a significant difference in means and medians between the market timers group and non-market timers group, I used (based on the previous literature) a regression model in which the dependent variable is estimated using a two-step process as follows:

First, I estimated the total accruals using the following equation: (Note 4)

$$
\begin{aligned}
\frac{\mathrm{TOTACC}_{i, t}}{\mathrm{TA}_{\mathrm{i}, \mathrm{t}-1}}=\alpha_{\mathrm{i}} \frac{1}{\mathrm{TA}_{\mathrm{i}, \mathrm{t}-1}}+ & \beta_{1 \mathrm{i}} \frac{\Delta \mathrm{REV}_{\mathrm{i}, \mathrm{t}}-\Delta \mathrm{REC}_{\mathrm{i}, \mathrm{t}}}{\mathrm{TA} \mathrm{A}_{\mathrm{i}, \mathrm{t}-1}}+\beta_{2 \mathrm{i}} \frac{\Delta \mathrm{PPE}_{\mathrm{i}, \mathrm{t}}}{\mathrm{TA} \mathrm{i}, \mathrm{t}-1}+\delta_{0 \mathrm{t}} \frac{\mathrm{CF}_{\mathrm{i}, \mathrm{t}-1}}{\mathrm{TA}_{\mathrm{i}, \mathrm{t}-1}}+\delta_{1 \mathrm{t}} \frac{\mathrm{CF}_{\mathrm{i}, \mathrm{t}}}{\mathrm{TA}_{\mathrm{i}, \mathrm{t}-1}}+\delta_{2 \mathrm{t}} \frac{\mathrm{CF}_{\mathrm{i}, \mathrm{t}+1}}{\mathrm{TA} \mathrm{i}, \mathrm{t}-1}+\delta_{3 \mathrm{t}} \frac{\mathrm{D} \Delta \mathrm{CF}_{\mathrm{i}, \mathrm{t}}}{\mathrm{TA} \mathrm{A}_{\mathrm{i}, \mathrm{t}-1}}+ \\
& \delta_{3 \mathrm{t}} \frac{\mathrm{D} \Delta \mathrm{CF} \mathrm{X} \Delta \mathrm{CF} \mathrm{F}_{\mathrm{i}, \mathrm{t}}}{\mathrm{TA} \mathrm{A}_{\mathrm{i}, \mathrm{t}-1}}+\varepsilon_{\mathrm{it}} .
\end{aligned}
$$

Then, I used the following equation to determine the discretionary accruals:

$$
\begin{aligned}
& \operatorname{DISCACCR}_{i, \mathrm{t}}=\frac{\mathrm{TOTACC}_{\mathrm{i}, \mathrm{t}}}{\mathrm{TA}_{\mathrm{i}, \mathrm{t}-1}}-\alpha_{\mathrm{i}} \frac{1}{\mathrm{TA}_{\mathrm{i}, \mathrm{t}-1}}+\beta_{1 \mathrm{i}} \frac{\Delta \mathrm{REV}_{\mathrm{i}, \mathrm{t}}-\Delta \mathrm{REC}_{\mathrm{i}, \mathrm{t}}}{\mathrm{TA} \mathrm{A}_{\mathrm{i}, \mathrm{t}-1}}+\beta_{2 \mathrm{i}} \frac{\Delta \mathrm{PPE}_{\mathrm{i}, \mathrm{t}}}{\mathrm{TA}_{\mathrm{i}, \mathrm{t}-1}}+\delta_{0 \mathrm{t}} \frac{\mathrm{CF}_{\mathrm{i}, \mathrm{t}-1}}{\mathrm{TA}_{\mathrm{i}, \mathrm{t}-1}}+\delta_{1 \mathrm{t}} \frac{\mathrm{CF}_{\mathrm{i}, \mathrm{t}}}{\mathrm{TA} \mathrm{A}_{\mathrm{i}, \mathrm{t}-1}}+\delta_{2 \mathrm{t}} \frac{\mathrm{CF}_{\mathrm{i}, \mathrm{t}+1}}{\mathrm{TA}_{\mathrm{i}, \mathrm{t}-1}}+ \\
& \delta_{3 \mathrm{t}} \frac{\mathrm{D} \Delta \mathrm{CF}_{\mathrm{i}, \mathrm{t}}}{\mathrm{TA}_{\mathrm{i}, \mathrm{t}-1}}+\delta_{3 \mathrm{t}} \frac{\mathrm{D} \Delta \mathrm{CF} \mathrm{x} \Delta \mathrm{CF}_{\mathrm{i}, \mathrm{t}}}{\mathrm{TA} \mathrm{A}_{\mathrm{i}, \mathrm{t}-1}}
\end{aligned}
$$

Once I estimated the discretionary accruals, I took the absolute value of that and developed my dependent variable ABS_DISCACCR. This estimation method is well-established in the literature as the best measure of discretionary accruals, for it also measures the quality of those accruals.

In addition to the dependent variable estimation and according to the literature (Note 5) I used the following regression model:

$$
\mid \text { DISCACCR }_{\mathrm{i}, \mathrm{t}} \mid=\text { Dtimers }_{\mathrm{i}, \mathrm{t}}+\mathrm{ROA}_{\mathrm{i}, \mathrm{t}}+\text { Size }_{\mathrm{i}, \mathrm{t}}+\text { Leverage }_{\mathrm{i}, \mathrm{t}}+\mathrm{BM}_{\mathrm{i}, \mathrm{t}}
$$

Where

$\mid$ DISCACCR $_{\mathrm{i}, \mathrm{t}} \mid=$ absolute discretionary accruals

Dtimers $_{i, \mathrm{t}}=$ a dummy variable that takes the value of one when companies time the market and the value of zero when companies do not time the market

$\mathrm{ROA}_{\mathrm{i}, \mathrm{t}}=\mathrm{a}$ control variable that reflect the returns on assets

Size $_{\mathrm{i}, \mathrm{t}}=\mathrm{a}$ control variable that reflects the size of companies (is the natural log of total assets)

Leverage $_{i, t}=a$ control variable that is believed to affect company resources; it measures how the company is financing its assets and is calculated as the total liabilities divided by common equity and retained earnings $\mathrm{BM}_{\mathrm{i}, \mathrm{t}}=\mathrm{a}$ control variable that measures the percentage of the book-to-market ratio

Before I started using the model, I tested for interaction among independent variable by using the Pearson correlation coefficients. These numbers measure the magnitude and direction of the linear relationship between the variables. Under $\mathrm{H}_{0}$ : Rho= 0 that the correlation (Rho) is zero. According to Table 8, the p-value for all the values is less than the significance level of (0.05); "therefore" I reject the null hypothesis of no correlation between the variables and conclude that there is actually correlation between the variables, which may lead to some specification problems or serial autocorrelation. However, it is worth noting that the correlation between the variables is not strong.

Table 8. Correlation Coefficients between Independent Variables

\section{Panel A}

\begin{tabular}{lllllll}
\hline Variable & N & Mean & Std Dev & Sum & Minimum & Maximum \\
\hline Size & 38623 & 5.50707 & 1.89670 & 212700 & 0.45742 & 10.05202 \\
BM & 29463 & 0.92279 & 2.23312 & 27188 & 0.01019 & 41.15385 \\
ROA & 51388 & 3.79927 & 14.68611 & 195237 & -46.04000 & 105.88000 \\
Leverage & 38623 & 0.55619 & 1.09114 & 21482 & 0 & 7.84177 \\
Size & 38623 & 5.50707 & 1.89670 & 212700 & 0.45742 & 10.05202 \\
Timers & 77484 & 0.60606 & 0.48862 & 46960 & 0 & 1.00000 \\
\hline
\end{tabular}


Panel B

\begin{tabular}{|c|c|c|c|c|c|c|}
\hline \multicolumn{7}{|c|}{$\begin{array}{c}\text { Pearson Correlation Coefficients } \\
\text { Prob }>|\mathbf{r}| \text { under H0: } \text { Rho }=0 \\
\text { Number of Observations }\end{array}$} \\
\hline & Size & BM & ROA & Leverage & Size & Timers \\
\hline $\begin{array}{l}\text { Size } \\
\text { (Size) }\end{array}$ & 1.00000 & $\begin{array}{r}-0.06826 \\
<.0001\end{array}$ & $\begin{array}{r}-0.01301 \\
0.0242\end{array}$ & $\begin{array}{r}0.10313 \\
<.0001\end{array}$ & 1.00000 & $\begin{array}{r}-0.04530 \\
<.0001\end{array}$ \\
\hline $\begin{array}{l}\text { BM } \\
\text { (Book-to-Market Ratio) }\end{array}$ & $\begin{array}{r}-0.06826 \\
<.0001\end{array}$ & 1.00000 & $\begin{array}{r}-0.03628 \\
<.0001\end{array}$ & $\begin{array}{r}0.16200 \\
<.0001\end{array}$ & $\begin{array}{r}-0.06826 \\
<.0001\end{array}$ & $\begin{array}{r}0.25865 \\
<.0001\end{array}$ \\
\hline ROA & $\begin{array}{r}-0.01301 \\
0.0242\end{array}$ & $\begin{array}{r}-0.03628 \\
<.0001\end{array}$ & 1.00000 & $\begin{array}{r}-0.11473 \\
<.0001\end{array}$ & $\begin{array}{r}-0.01301 \\
0.0242\end{array}$ & $\begin{array}{r}0.08975 \\
<.0001\end{array}$ \\
\hline $\begin{array}{l}\text { Leverage } \\
\text { (Leverage) }\end{array}$ & $\begin{array}{r}0.10313 \\
<.0001\end{array}$ & $\begin{array}{r}0.16200 \\
<.0001\end{array}$ & $\begin{array}{r}-0.11473 \\
<.0001\end{array}$ & 1.00000 & $\begin{array}{r}0.10313 \\
<.0001\end{array}$ & $\begin{array}{r}0.03017 \\
<.0001\end{array}$ \\
\hline $\begin{array}{l}\text { Size } \\
\text { (Size) }\end{array}$ & 1.00000 & $\begin{array}{r}-0.06826 \\
<.0001\end{array}$ & $\begin{array}{r}-0.01301 \\
0.0242\end{array}$ & $\begin{array}{r}0.10313 \\
<.0001\end{array}$ & 1.00000 & $\begin{array}{r}-0.04530 \\
<.0001\end{array}$ \\
\hline $\begin{array}{l}\text { Timers } \\
\text { (Companies Timing the Market) }\end{array}$ & $\begin{array}{r}-0.04530 \\
<.0001\end{array}$ & $\begin{array}{r}0.25865 \\
<.0001\end{array}$ & $\begin{array}{r}0.08975 \\
<.0001\end{array}$ & $\begin{array}{r}0.03017 \\
<.0001\end{array}$ & $\begin{array}{r}-0.04530 \\
<.0001\end{array}$ & 1.00000 \\
\hline
\end{tabular}

* Significant at the $5 \%$ level.

\section{Regression Diagnostics and Hypothesis Results}

One of the main assumptions of the Ordinary Least Square (OLS) regression is the homogeneity of variance of the residuals. A commonly used graphical design is to plot the residuals versus predicted values. Figure 1 shows the structure of the data points widening toward the right side, which is an indication of mild heteroscedasticity.

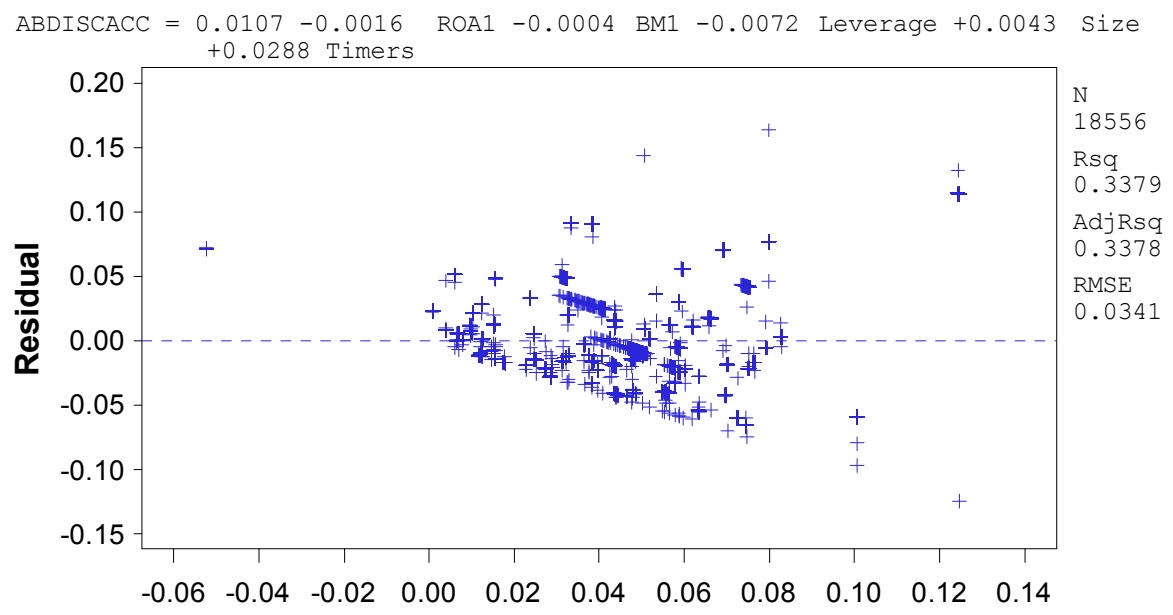

Predicted Value

Figure 1.

I ran diagnostic statistics on my regression model:

$$
\mid \text { DISCACCR }_{i, t} \mid=\text { Dtimer }_{i, t}+\text { ROA }_{i, t}+\text { Size }_{i, t}+\text { Leverage }_{i, t}++B M_{i, t}
$$


According to Table 9, panel (A), the $F$ statistic $=1893.67$, with a $p$-value $<(0.0001)$, that means the independent variables are not all equal, and they are significantly different from zero. Table 9, panel (B) shows the parameter estimates and the dummy variable DTIMERS are positive and significant at the (0.05) significance level, which suggests that companies that time the market are engaging in earnings management since they contribute positively to the discretionary accruals; however, further investigation is still warranted.

To check on the degree of multicollinearity, I will use the variance inflation factor (VIF), and a variable whose VIF values are greater than 10 may warrant further investigation. I explain tolerance as $1 / \mathrm{VIF}$, to check on the degree of collinearity, and as such, tolerance values lower than 0.1 is equivalent to a VIF of 10. It means that the variable could be considered as a linear combination of other independent variables. I also eliminate the intercept from those calculations, but it is still included in the calculation of the regression. Table 9, panel (B) shows that, the VIF for all the independent variables is less than two and tolerance is less than 1 , which means we do not have a case of complete multicollinearity. To investigate the issue of multicollinearity, I calculate the condition number, which is a commonly used index of the global instability of the regression coefficients-large condition number, 10 or more, is an indication of instability. The output produced in Table 9 panel (C) contains the Eigenvalues of the regressors and they are ranked from highest to lowest. As long as no significant differences are evident among the Eigenvalues (large variability), then there is no strong degree of multicollinearity. Freund and Littell (2000) and Myers (1990), report that small Eigenvalues represent near-perfect linear dependencies or high multicollinearity. According to Table 9, panel (C), the Eigenvalues corresponding to the independent variables are not particularly small. The square root of the ratio of the largest Eigenvalues to the smallest Eigenvalues is given by the last element in the condition number column. According to Myers (1990) since the condition number for the independent variables are not high, then they do not have a high degree of multicollinearity. Table 9, panel (C) shows that the condition numbers for the independent variables are between 1 and 1.9, indicating a remarkably mild case of multicollinearity. The White exam tests the null hypothesis that the variance of the residuals is homogenous. According to Table 9, panel (D), since the p-value is extremely small $(<0.001)$, I will reject the hypothesis of homoscedasticity and accept the alternative hypothesis that the variance is not homogenous.

Table 9. Regression Diagnostic for the Model (cont)

$$
\mid \text { ADISCACCR }_{i, t} \mid=\text { Dtimers }_{i, t}+\text { ROA }_{i, t}+B M_{i, t}+\text { Leverage }_{i, t}+\text { Size }_{i, t}
$$

Panel A

\begin{tabular}{lrrrrr}
\hline \multicolumn{5}{c}{ Analysis of Variance } & \\
\hline Source & DF & Sum of Squares & Mean Square & F Value & Pr > F \\
\hline Model & 5 & 11.03839 & 2.20768 & 1893.67 & $<.0001$ \\
Error & 18550 & 21.62596 & 0.00117 & & \\
Corrected Total & 18555 & 32.66435 & & & \\
\hline
\end{tabular}

Panel B

\begin{tabular}{lrrrrrr}
\hline Variable & $\begin{array}{r}\text { Parameter } \\
\text { Estimate }\end{array}$ & $\begin{array}{r}\text { Standard } \\
\text { Error }\end{array}$ & t Value & Pr $>|\mathbf{t}|$ & Tolerance & $\begin{array}{r}\text { Variance } \\
\text { Inflation }\end{array}$ \\
\hline Intercept & 0.01072 & 0.00111 & 9.68 & $<.0001$ &. & 0 \\
ROA & -0.00157 & 0.00001896 & -83.05 & $<.0001$ & 0.89799 & 1.11360 \\
BM & -0.00038102 & 0.00011380 & -3.35 & 0.0008 & 0.91659 & 1.09101 \\
Leverage & -0.00723 & 0.00035403 & -20.43 & $<.0001$ & 0.94276 & 1.06072 \\
Size & 0.00435 & 0.00018326 & 23.71 & $<.0001$ & 0.88276 & 1.13281 \\
Timers & 0.02880 & 0.00052236 & 55.14 & $<.0001$ & 0.92999 & 1.07528 \\
\hline
\end{tabular}


Panel C.

\begin{tabular}{|c|c|c|c|c|c|c|c|}
\hline \multicolumn{8}{|c|}{ Collinearity Diagnostics (intercept adjusted) } \\
\hline \multirow[t]{2}{*}{ Number } & \multirow[t]{2}{*}{ Eigenvalue } & \multirow{2}{*}{$\begin{array}{r}\text { Condition } \\
\text { Index }\end{array}$} & \multicolumn{5}{|c|}{ Proportion of Variation } \\
\hline & & & ROA & $\mathbf{B M}$ & Leverage & Size & Timers \\
\hline 1 & 1.37670 & 1.00000 & 0.25380 & 0.00497 & 0.01101 & 0.25545 & 0.12765 \\
\hline 2 & 1.22521 & 1.06002 & 0.04708 & 0.42349 & 0.17753 & 0.02220 & 0.08209 \\
\hline 3 & 1.04639 & 1.14702 & 0.00271 & 0.02045 & 0.47633 & 0.09168 & 0.29874 \\
\hline 4 & 0.72533 & 1.37769 & 0.52395 & 0.24544 & 0.01765 & 0.13058 & 0.33552 \\
\hline 5 & 0.62637 & 1.48253 & 0.17246 & 0.30565 & 0.31748 & 0.50009 & 0.15599 \\
\hline
\end{tabular}

Panel D

\begin{tabular}{ccr}
\hline \multicolumn{2}{c}{ Test of First and Second Moment Specification } \\
\hline DF & Chi-Square & Pr $>$ ChiSq \\
\hline 20 & 2909.54 & $<.0001$
\end{tabular}

Since I rejected the hypothesis of homoscedasticity, then I want to determine the asymptotic covariance matrix of the estimates under the hypothesis of heteroscedasticity. Table 10 Panels (B) and (C) show that the point estimates of the coefficients are exactly the same as in ordinary OLS - as shown in Table 10, panel (C) but the standard errors are calculated based on the asymptotic covariance matrix. Note the changes are in the standard errors and t-tests (but no change in the coefficients).

Table 10. Robust Standard Error Regression Model

$$
\mid \text { ADISCACCR }_{i, t} \mid=\text { Dtimers }_{i, t}+\text { ROA }_{i, t}+B M_{i, t}+\text { Leverage }_{i, t}+\text { Size }_{i, t}
$$

Panel A

\begin{tabular}{lrrrrrrr}
\hline Variable & $\begin{array}{r}\text { Parameter } \\
\text { Estimate }\end{array}$ & $\begin{array}{r}\text { Standard } \\
\text { Error }\end{array}$ & $\mathbf{t}$ Value & Pr $>|\mathbf{t}|$ & \multicolumn{3}{c}{ Heteroscedasticity Consistent } \\
\cline { 5 - 8 } & & & & & $\begin{array}{r}\text { Standard } \\
\text { Error }\end{array}$ & $\begin{array}{c}\mathbf{t} \text { Value } \\
\text { Pr }>|\mathbf{t}|\end{array}$ \\
\hline Intercept & 0.01072 & 0.00111 & 9.68 & $<.0001$ & 0.00114 & 9.41 & $<.0001$ \\
ROA & -0.00157 & 0.00001896 & -83.05 & $<.0001$ & 0.00003200 & -49.20 & $<.0001$ \\
BM & -0.00038102 & 0.00011380 & -3.35 & 0.0008 & 0.00007052 & -5.40 & $<.0001$ \\
Leverage & -0.00723 & 0.00035403 & -20.43 & $<.0001$ & 0.00025551 & -28.31 & $<.0001$ \\
Size & 0.00435 & 0.00018326 & 23.71 & $<.0001$ & 0.00018300 & 23.75 & $<.0001$ \\
Timers & 0.02880 & 0.00052236 & 55.14 & $<.0001$ & 0.00054753 & 52.60 & $<.0001$ \\
\hline
\end{tabular}


Panel C

\begin{tabular}{lrrrrrr}
\hline Variable & $\begin{array}{r}\text { Parameter } \\
\text { Estimate }\end{array}$ & $\begin{array}{r}\text { Standard } \\
\text { Error }\end{array}$ & $\begin{array}{r}\text { t Value } \\
\text { Intercept }\end{array}$ & $\begin{array}{l}\text { Pr }>|\mathbf{t}| \\
\text { ROA }\end{array}$ & ROBUST_STDERR & TVALUE_RB \\
BM & -0.01072 & 0.00111 & 9.68 & $<.0001$ & 0.001146 & 9.353653 \\
Leverage & -0.00038102 & 0.00011380 & -3.35 & 0.0008 & 0.000032 & -48.8892 \\
Size & -0.00723 & 0.00035403 & -20.43 & $<.0001$ & 0.000071 & -5.36851 \\
Timers & 0.00435 & 0.00018326 & 23.71 & $<.0001$ & 0.000257 & -28.1257 \\
\hline
\end{tabular}

\section{Robustness Check}

\subsection{Detecting and Correcting for Heteroscedasticity}

Since I established that the data suffer from heteroscedasticity, and Verbeek (2004) notes there are regular tests for detecting the presence of non-spherical disturbances: White's standard test, the Goldfeld-Quand t-test, and the Breusch-Pagan test.

To conduct the investigation; first, I define the parameters of the model as Const (for the intercept), C_Timers (TIMERS), C_BM (BM), C_Size (Size), C Leverage (Leverage), C_ROA (ROA). I will be regressing ABS_DISCACRR against Timers, BM, Size, Leverage, and ROA. Table 11, panel (C) shows that the test-statistic value for White's test has a p-value equal (0.0001). Therefore, I reject the null hypothesis of homoscedastic disturbances. The Breusch-Pagan test yields the same results; hence, I reject the null hypothesis of homoscedastic disturbances.

Table 11. Testing for Heteroscedasticity in the Regression Model

$$
\mid \text { ADISCACCR }_{i, t} \mid=\text { Dtimers }_{i, t}+\text { ROA }_{i, t}+\text { BM }_{i, t}+\text { Leverage }_{i, t}+\text { Size }_{i, t}
$$

Panel A

\begin{tabular}{|c|c|c|c|c|c|c|c|}
\hline \multicolumn{8}{|c|}{ The Equation to Estimate is } \\
\hline \multicolumn{3}{|c|}{ ABDISCACC $=$} & C_BM(B & LLeverag & erage), C_Siz & ), C_Timers & ers)) \\
\hline \multicolumn{8}{|c|}{ Nonlinear OLS Summary of Residual Errors } \\
\hline Equation & DF Model & DF Error & SSE & MSE & Root MSE & R-Square & Adj R-Sq \\
\hline ABDISCACC & 6 & 18550 & 21.6260 & 0.00117 & 0.0341 & 0.3379 & 0.3378 \\
\hline
\end{tabular}

Panel B

\begin{tabular}{lrrrr}
\hline \multicolumn{5}{c}{ Nonlinear OLS Parameter Estimates } \\
\hline Parameter & Estimate & $\begin{array}{l}\text { Approx } \\
\text { Std Err }\end{array}$ & t Value & $\begin{array}{c}\text { Approx } \\
\text { Pr }>|\mathbf{t}|\end{array}$ \\
\hline Const & 0.010718 & 0.00111 & 9.68 & $<.0001$ \\
C_ROA & -0.00157 & 0.000019 & -83.05 & $<.0001$ \\
C_BM & -0.00038 & 0.000114 & -3.35 & 0.0008 \\
C_Leverage & -0.00723 & 0.000354 & -20.43 & $<.0001$ \\
C_Size & 0.004346 & 0.000183 & 23.71 & $<.0001$ \\
C_Timers & 0.0288 & 0.000522 & 55.14 & $<.0001$ \\
\hline
\end{tabular}

Panel C

\begin{tabular}{llrrrl}
\hline \multicolumn{7}{c}{ Heteroscedasticity Test } \\
\hline Equation & Test & Statistic & DF & Pr $>$ ChiSq & Variables \\
\hline ABDISCACC & White's Test & 9103 & 19 & $<.0001$ & Cross of all vars \\
& Breusch-Pagan & 4371 & 2 & $<.0001$ & 1 , Timers, ROA \\
\hline
\end{tabular}


To compute the generalized least squares (GLS) estimator, first, I must alter the response variable, second calculate the weighted explanatory variables according to Greene (2003) and Verbeek (2004. Until now the assumption was that when $\{\varepsilon \mid \mathrm{X}\}=\sigma^{2} \mho$, where $\mho$ is a positive definite, symmetric matrix, it is known. However, when $\mho$ is assumed to be unknown, the unrestricted heteroscedastic regression model will take too many parameters, and it will be difficult to estimate. However, according to Green (2003) and Verbeek (2004), by expressing $\sigma^{2} \mho$ as a function of only a few parameters, for example, the parameter $\alpha$, and accordingly, the analysis could have more than one variable, making the parameter $(\alpha)$ a vector. The modified variance-covariance matrix can now be denoted as $\mho(\alpha)$. Therefore, estimating $\mho$ is now restricted to estimating $(\alpha)$. Green (2003) and Verbeek (2004) report that either use the two-step FGLS technique or use the maximum likelihood estimation. I will use the two-step FGLS estimator.

The analysis results are given in Table 12. I estimated FGLS by applying the idea that the variance of the disturbances is proportional to the expected value of the residual of the vector parameter. Table 12, panel (B) shows that DTIMERS with t-statistic of 45.26 and $p$-value of $<0.0001$ is still positive and significant at the 0.05 significance level.

Table 12. Using FGLS to Estimate the Regression Model

Weight: 1/exp (pred)

$\mid$ ADISCACCR $_{i, t} \mid=$ Dtimers $_{i, t}+$ ROA $_{i, t}+B M_{i, t}+$ Leverage $_{i, t}+$ Size $_{i, t}$

Panel A

\begin{tabular}{lrcrrr}
\hline \multicolumn{5}{c}{ Analysis of Variance } \\
\hline Source & DF & $\begin{array}{r}\text { Sum of } \\
\text { Squares }\end{array}$ & $\begin{array}{r}\text { Mean } \\
\text { Square }\end{array}$ & F Value & Pr > F \\
\hline Model & 5 & 17439 & 3487.80970 & 1164.51 & $<.0001$ \\
Error & 18550 & 55559 & 2.99509 & & \\
Corrected Total & 18555 & 72998 & & & 0.2389 \\
Root MSE & \multicolumn{2}{c}{1.73063} & R-Square & & 0.2387 \\
Dependent Mean & \multicolumn{2}{c}{0.03656} & Adj R-Sq & & \\
Coeff Var & 4733.95353 & & & & \\
\hline
\end{tabular}

Panel B

\begin{tabular}{lrrrr}
\hline Variable & $\begin{array}{r}\text { Parameter } \\
\text { Estimate }\end{array}$ & $\begin{array}{r}\text { Standard } \\
\text { Error }\end{array}$ & t Value & Pr $>|\mathbf{t}|$ \\
\hline Intercept & 0.01533 & 0.00099132 & 15.46 & $<.0001$ \\
ROA & -0.00123 & 0.00002171 & -56.46 & $<.0001$ \\
BM & 0.00020204 & 0.00009576 & 2.11 & 0.0349 \\
Leverage & -0.00713 & 0.00028273 & -25.20 & $<.0001$ \\
Size & 0.00382 & 0.00015513 & 24.63 & $<.0001$ \\
Timers & 0.01967 & 0.00043453 & 45.26 & $<.0001$ \\
\hline
\end{tabular}

Enders (2004) postulated time-series variance is cont constant, and Greene (2003) when the variance of the disturbance is assumed to depend on the variance of the disturbance in the previous time periods, then the time-series is hterosecasdictic. Engle's (1982) autoregressive, conditionally heteroscedastic models (ARCH) assumes hetrosecasdictic variance. He proposed a methodology where the variances of the disturbances are not constant and depend on its past.

The simplest form of Engle's ARCH model is the ARCH (1) model. To test for ARCH effect the Lagrange Multiplier test (LM) is used to test for ARCH (q) effects. The hypothesis tested is under the null hypothesis; there are $\mathrm{ARCH}$ effects and the alternative hypothesis that there are no ARCH effects. Table 15, panel (A) show the values for SSE and MSE, which are for the error and mean sums of squares, respectively. The MSE is the unconditional variance of the series. The Durbin-Watson statistic is used to test for serial correlation. The values of AIC (Akaike information criterion) and BIC are information criterion values that are used to assess model fit. Smaller values of the statistics are desirable. Table 13, panel (B) contains the Q and LM tests. Both statistics test for heteroscedasticity in the time-series. The Q statistic proposed by McLeod and Li (1983), and the test is highly significant across the twelve lag windows. The LM statistic is highly significant across all twelve lags indicating that a higher order ARCH process will be appropriate to model the data. 
Table 13. Testing for ARCH Process

Panel A

\begin{tabular}{lrlr}
\hline Dependent Variable & \multicolumn{2}{c}{ ABDISCACC } \\
\hline \multicolumn{4}{c}{ Ordinary Least Squares Estimates } \\
\hline SSE & 122.459994 & DFE & 50897 \\
MSE & 0.00241 & Root MSE & 0.04905 \\
SBC & -162451.38 & AIC & -162460.21 \\
MAE & 0.07091067 & AICC & -162460.21 \\
MAPE & $1.5999 \mathrm{E} 14$ & Regress R-Square & 0.0000 \\
Durbin-Watson & 0.0119 & Total R-Square & 0.0000 \\
\hline
\end{tabular}

Panel B

\begin{tabular}{crrrr}
\hline \multicolumn{5}{c}{ Q and LM Tests for ARCH Disturbances } \\
\hline Order & $\mathbf{Q}$ & $\mathbf{P r}>\mathbf{Q}$ & $\mathbf{L M}$ & $\mathbf{P r}>\mathbf{L M}$ \\
\hline $\mathbf{1}$ & 49843.8143 & $<.0001$ & 49840.8778 & $<.0001$ \\
$\mathbf{2}$ & 99363.2883 & $<.0001$ & 49964.2755 & $<.0001$ \\
$\mathbf{3}$ & 148509.792 & $<.0001$ & 49974.7487 & $<.0001$ \\
$\mathbf{4}$ & 197283.733 & $<.0001$ & 49975.5736 & $<.0001$ \\
$\mathbf{5}$ & 245686.523 & $<.0001$ & 49975.6218 & $<.0001$ \\
$\mathbf{6}$ & 293719.570 & $<.0001$ & 49975.6222 & $<.0001$ \\
$\mathbf{7}$ & 341384.286 & $<.0001$ & 49975.6235 & $<.0001$ \\
$\mathbf{8}$ & 388682.082 & $<.0001$ & 49975.6261 & $<.0001$ \\
$\mathbf{9}$ & 435614.366 & $<.0001$ & 49975.6293 & $<.0001$ \\
$\mathbf{1 0}$ & 482182.552 & $<.0001$ & 49975.6326 & $<.0001$ \\
$\mathbf{1 1}$ & 528388.048 & $<.0001$ & 49975.6360 & $<.0001$ \\
$\mathbf{1 2}$ & 574232.266 & $<.0001$ & 49975.6394 & $<.0001$ \\
\hline
\end{tabular}

Bollerslev (1986) extended the ARCH, and the result is the generalized autoregressive conditional heteroscedastic model or GARCH. Baltagi (2008) the LM test can also be used for testing GARCH effects. In a test for a GARCH (p, q) model, however, the hypothesis tested is the null of an $\mathrm{ARCH}$ (q) process versus an $\mathrm{ARCH}(\mathrm{p}+\mathrm{q})$ process here. Greene (2003) reports that the MLE can be used to estimate the parameters of both the ARCH and GARCH models. The analysis results are given in Table 14 panel (B) indicates that there is strong evidence of GARCH effects (p-value $<0.0001)$. The normality test is highly significant ( $\mathrm{p}$-value $<0.0001)$, which indicates that the residuals from the GARCH model are not normally distributed. $\mathrm{ARCH}_{0}$ gives the estimate of $\alpha_{0}, \mathrm{ARCH}_{1}$ gives the estimate of $\alpha_{1}$, and GARCH1 gives the estimate of $\beta_{1}$.

Table 14. Testing for GARCH Process

Panel A

Panel B

\begin{tabular}{lrlr}
\hline Dependent Variable & \multicolumn{2}{c}{ ABDISCACC } \\
\hline \multicolumn{4}{c}{ Ordinary Least Squares Estimates } \\
\hline SSE & 122.459994 & DFE & 50897 \\
MSE & 0.00241 & Root MSE & 0.04905 \\
SBC & -162451.38 & AIC & -162460.21 \\
MAE & 0.03545534 & AICC & -162460.21 \\
MAPE & $1.5999 E 14$ & Regress R-Square & 0.0000 \\
Durbin-Watson & 0.0119 & Total R-Square & 0.0000 \\
\hline
\end{tabular}

\begin{tabular}{|c|c|c|c|c|c|c|}
\hline Variable & DF & Estimate & Standa & rd Error & t Value & $\begin{array}{r}\text { Approx } \\
r>|t|\end{array}$ \\
\hline Intercept & 1 & 0.0443 & & 0.000217 & 203.69 & $<.0001$ \\
\hline \multicolumn{7}{|c|}{ GARCH Estimates } \\
\hline SSE & \multicolumn{3}{|c|}{165.898982} & \multicolumn{2}{|c|}{ Observations } & 50898 \\
\hline SBC & \multicolumn{3}{|c|}{-275634.11} & \multicolumn{2}{|l|}{ AIC } & -275669.46 \\
\hline MAE & \multicolumn{3}{|c|}{0.03413364} & \multicolumn{2}{|l|}{ AICC } & -275669.46 \\
\hline \multirow[t]{2}{*}{ MAPE } & \multirow{2}{*}{\multicolumn{3}{|c|}{$5.44527 \mathrm{E} 13$}} & \multicolumn{2}{|c|}{ Normality Test } & 2989434.15 \\
\hline & & & & \multicolumn{2}{|c|}{$\operatorname{Pr}>\mathrm{ChiSq}$} & $<.0001$ \\
\hline
\end{tabular}

The output indicates that there is strong evidence of GARCH effects ( $p$ value $<0.0001$ ). 
Panel C

\begin{tabular}{lrrrrr}
\hline Variable & DF & Estimate & Standard Error & t Value & Approx Pr $>|\mathbf{t}|$ \\
\hline Intercept & 1 & 0.0151 & $2.5103 \mathrm{E}-6$ & 6004.55 & $<.0001$ \\
ARCH0 & 1 & $2.4298 \mathrm{E}-7$ & $1.2791 \mathrm{E}-9$ & 189.96 & $<.0001$ \\
ARCH1 & 1 & 0.4967 & 0.001828 & 271.70 & $<.0001$ \\
GARCH1 & 1 & 0.5040 & 0.001831 & 275.29 & $<.0001$ \\
\hline
\end{tabular}

(pvalue $<0.0001$ ), which indicates that the residuals from the GARCH model are not normally distributed

Having established the presence of ARCH and GARCH and the need for higher order ARCH process to model the data then I used ARCH (7) and GARCH (2) process. The output in Table 15, panel (B) shows that ARCH (5) the t-statistic is (2.66) with a p-value (0.0078), which renders ARCH (5) significant. Moreover, GARCH (1) with a t-statistic (0.51) with a p-value (0.6076) renders GARCH (1) insignificant. The above analysis leads to the assumptions that there is a high degree of autocorrelation

Table 15. Using ARCH (5) and GARCH (2) to Estimate the Regression Model

\begin{tabular}{|c|c|c|c|c|}
\hline \multicolumn{5}{|c|}{ GARCH Estimates } \\
\hline & SSE & 34.1807571 & Observations & 18556 \\
\hline & MSE & 0.00184 & Uncond Var & \\
\hline & Log Likelihood & 54889.3382 & Total R-Square & \\
\hline & SBC & -109641.08 & AIC & -109750.68 \\
\hline & MAE & 0.02672774 & AICC & -109750.65 \\
\hline & MAPE & $2.20345 \mathrm{E} 13$ & Normality Test & 1993885.76 \\
\hline & & & Pr $>$ ChiSq & $<.0001$ \\
\hline
\end{tabular}

Panel B

\begin{tabular}{lrrrrr}
\hline Variable & DF & Estimate & Standard Error & t Value & Approx Pr $>|\mathbf{t}|$ \\
\hline Intercept & 1 & 0.003686 & 0.0000120 & 307.50 & $<.0001$ \\
ROA & 1 & -0.000412 & $2.4267 \mathrm{E}-7$ & -1699.7 & $<.0001$ \\
BM & 1 & 0.001502 & $7.889 \mathrm{E}-6$ & 190.33 & $<.0001$ \\
Leverage & 1 & -0.007340 & $7.7514 \mathrm{E}-6$ & -946.91 & $<.0001$ \\
Size & 1 & 0.004716 & $1.8807 \mathrm{E}-6$ & 2507.44 & $<.0001$ \\
Timers & 1 & -0.002076 & $7.9254 \mathrm{E}-6$ & -261.99 & $<.0001$ \\
ARCH0 & 1 & $6.1469 \mathrm{E}-7$ & $1.2316 \mathrm{E}-8$ & 49.91 & $<.0001$ \\
ARCH1 & 1 & 0.2073 & 0.003284 & 63.12 & $<.0001$ \\
ARCH2 & 1 & 0.1973 & 0.0294 & 6.71 & $<.0001$ \\
ARCH3 & 1 & 0.1944 & 0.0857 & 2.27 & 0.0233 \\
ARCH4 & 1 & 0.1930 & 0.0970 & 1.99 & 0.0466 \\
ARCH5 & 1 & 0.1915 & 0.0720 & 2.66 & 0.0078 \\
GARCH1 & 1 & 0.0101 & 0.0196 & 0.51 & 0.6076 \\
GARCH2 & 1 & 0.006789 & 0.008647 & 0.79 & 0.4324 \\
\hline
\end{tabular}

\subsection{Detecting and Correcting for Autocorrelation and Heteroscedasticity}

Autocorrelation in regression models often occurs when models are miss-specified or when variables are mistakenly omitted from the model. In the omitted variable case, unobserved or omitted variables that are correlated over time are now absorbed in the error term, causing autocorrelation. In addition, if the assumption that the disturbance related to an observation is independent of the disturbance related to another observation, in that case this situation is called serial correlation or autocorrelation. Autocorrelation also implies that the errors are heteroscedastic (Greene, 2003, p. 258). OLS estimators, although unbiased, will be ineffective and will have incorrect standard errors. Estimation techniques under the notion of serial correlation parallel the estimation methods for heteroscedasticity. That is an estimate of the variance-covariance matrix is needed. The GLS estimator can be calculated using the Prais-Winsten transformations by using the variance and covariance, matrix of the disturbances. However, the traditional approach 
for the transformation is done by using the Cochrane and Orcutt (1949) method in which they dropped the first observation for computational ease. Verbeek (2004, p. 100) finds deleting the observation leads to an approximate GLS estimator that is not as efficient as the GLS estimator obtained by including all the observations. Greene (2003) extends the process to the second-order autocorrelation process, which can become exceedingly complex as the order of the autoregressive process increases.

To detect autocorrelation, the Durbin-Watson test is perhaps the most commonly used test, testing the null hypothesis of no autocorrelation. The LM test suggested by Breusch and Godfrey (1978) is an alternative to the Durbin-Watson test. The test-statistic has a chi-squared distribution with $\mathrm{p}$ degrees of freedom. The output in Table 16, panel (B) reveals that the DW statistic of 0.0211 with $\operatorname{Pr}<.0001$ for $\operatorname{Pr}<\mathrm{DW}$, which is highly significant for testing positive serial autocorrelation, and with $\operatorname{Pr}>1.0000$ for $\operatorname{Pr}>\mathrm{DW}$, which is insignificant for negative serial autocorrelation. The LM test with a $p$-value of $<0.0001$ indicates that the significance extends to the higher order autoregressive process.

Table 16. Testing for Auto Correlation

Panel A

\begin{tabular}{lrlr}
\hline \multicolumn{4}{c}{ Ordinary Least Squares Estimates } \\
\hline SSE & 21.6259607 & DFE & 18550 \\
MSE & 0.00117 & Root MSE & 0.03414 \\
SBC & -72620.741 & AIC & -72667.713 \\
MAE & 0.0261328 & AICC & -72667.708 \\
MAPE & $3.56131 \mathrm{E} 13$ & Regress R-Square & 0.3379 \\
Durbin-Watson & 0.0211 & Total R-Square & 0.3379 \\
\hline
\end{tabular}

Panel B

\begin{tabular}{crrr}
\hline \multicolumn{4}{c}{ Durbin-Watson Statistics } \\
\hline Order & DW & $\operatorname{Pr}<$ DW & $\operatorname{Pr}>$ DW \\
$\mathbf{1}$ & 0.0211 & $<.0001$ & 1.0000 \\
\hline
\end{tabular}

Panel C

\begin{tabular}{lrr}
\hline \multicolumn{3}{c}{ Godfrey's Serial Correlation Test } \\
\hline Alternative & \multicolumn{1}{c}{ LM } & Pr $>$ LM \\
\hline AR(1) & 18164.0022 & $<.0001$ \\
AR(2) & 18195.1047 & $<.0001$ \\
AR(3) & 18196.9657 & $<.0001$ \\
AR(4) & 18197.0637 & $<.0001$ \\
\hline
\end{tabular}

Having detected the presence of autocorrelation, I will estimate the parameters by using either GLS or FGLS. The first step is to determine the degree of the autoregressive process. I ran a back-step regression where the model eliminates the lags that have an insignificant t-statistic. Table 17, panel (A) reports an estimate of the first three order autocorrelations, and as it shows, they are all significant. Panel (B) reports the results of the back-step regression model where lag 1,2 , and has a t-statistic of $-88.99,-29.35$, and -12.69 , respectively, and they are all significant. The results imply that the autoregressive model should be of a high order and probably between 10 and 14 .

Table 17. Back-step Regression to Determine the Degree of the AR Process

Panel A

\begin{tabular}{rrrr}
\hline \multicolumn{4}{c}{ Estimates of Autocorrelations } \\
\hline Lag & Covariance & Correlation & -198765432101234567891 \\
\hline $\mathbf{0}$ & 0.00117 & 1.000000 & $|* * * * * * * * * * * * * * * * * * * *|$ \\
$\mathbf{1}$ & 0.00115 & 0.990373 & $|* * * * * * * * * * * * * * * * * * * *|$ \\
$\mathbf{2}$ & 0.00115 & 0.986849 & $|* * * * * * * * * * * * * * * * * * * *|$ \\
$\mathbf{3}$ & 0.00115 & 0.983037 & $|* * * * * * * * * * * * * * * * * * * *|$ \\
\hline
\end{tabular}


Panel B

\begin{tabular}{rcrr}
\hline \multicolumn{4}{c}{ Estimates of Autoregressive Parameters } \\
\hline Lag & Coefficient & $\begin{array}{c}\text { Standard } \\
\text { Error }\end{array}$ & t Value \\
& & 0.007311 & -88.99 \\
$\mathbf{1}$ & -0.650646 & 0.008538 & -29.35 \\
$\mathbf{3}$ & -0.250598 & 0.007311 & -12.69 \\
& -0.092762 & Yule-Walker Estimates \\
SSE & 0.34105422 & DFE & 18547 \\
MSE & 0.0000184 & Root MSE & 0.00429 \\
SBC & \multicolumn{2}{c}{ AIC } \\
MAE & 0.00053635 & AICC &. \\
MAPE & $1.77291 E 13$ & Regress R-Square & 0.0230 \\
& & Total R-Square & 0.9896 \\
\hline
\end{tabular}

Panel C

\begin{tabular}{cccr}
\hline \multicolumn{4}{c}{ Durbin-Watson Statistics } \\
\hline Order & DW & Pr $<$ DW & Pr $>$ DW \\
\hline $\mathbf{1}$ & 1.6493 & $<.0001$ & 1.0000 \\
$\mathbf{2}$ & 1.9019 & $<.0001$ & 1.0000 \\
$\mathbf{3}$ & 2.0069 & 0.6858 & 0.3142 \\
\hline
\end{tabular}

The next step is to re-estimate the model while adjusting for both autocorrelations using an AR order of fourteen and adjusting for heteroscedasticity using the GARCH method of an order $(q=3)$. The FGLS estimates are then reported, assuming the AR (14) model, and GARCH ( $\mathrm{q}=3)$. Table 18, panel (C) shows the final estimate of the model after using AR(14) and GARCH ( $\mathrm{q}=3)$ and reports that DTIMERS has a t-statistic of 3.66 with a p-value of $<0.0003$, which is highly positive and significant, and confirms that companies that time the market engage in earnings management. Panel (C) also reports that AR5 with a p-value 0.8233 is insignificant at the 0.05 level and that ARCH (2) and GARCH (1) are both insignificant with a p-value (1.000). The above analysis proves that after adjusting for autocorrelation and heteroscedasticity the portfolio of companies who time the market that is the companies who cross-list their IPO while the host market is a positive then these companies are more likely to engage in earning management. The analysis explain why these firms achieved negative abnormal returns post their IPOs while other firms who did not time the market achieve positive abnormal returns post their IPOs.

Table 18. AR (14) and GARCH (3) Are Used to Estimate the Regression

Panel A

\begin{tabular}{llll}
\hline \multicolumn{3}{c}{ Estimates of Autoregressive Parameters } \\
\hline Lag & Coefficient & Standard Error & t Value \\
\hline $\mathbf{1}$ & -0.648102 & 0.007345 & -88.24 \\
$\mathbf{2}$ & -0.243829 & 0.008753 & -27.86 \\
$\mathbf{3}$ & -0.075037 & 0.008934 & -8.40 \\
$\mathbf{4}$ & -0.022427 & 0.008951 & -2.51 \\
$\mathbf{5}$ & -0.006806 & 0.008952 & -0.76 \\
$\mathbf{6}$ & -0.002069 & 0.008953 & -0.23 \\
$\mathbf{7}$ & 0.000000588 & 0.008953 & 0.00 \\
$\mathbf{8}$ & -0.000327 & 0.008953 & -0.04 \\
$\mathbf{9}$ & 0.000138 & 0.008953 & 0.02 \\
$\mathbf{1 0}$ & 0.000404 & 0.008952 & 0.05 \\
$\mathbf{1 1}$ & -0.001719 & 0.008951 & -0.19 \\
$\mathbf{1 2}$ & 0.004001 & 0.008934 & 0.45 \\
$\mathbf{1 3}$ & 0.000409 & 0.008753 & 0.05 \\
$\mathbf{1 4}$ & 0.001302 & 0.007345 & 0.18 \\
\hline
\end{tabular}


Panel B

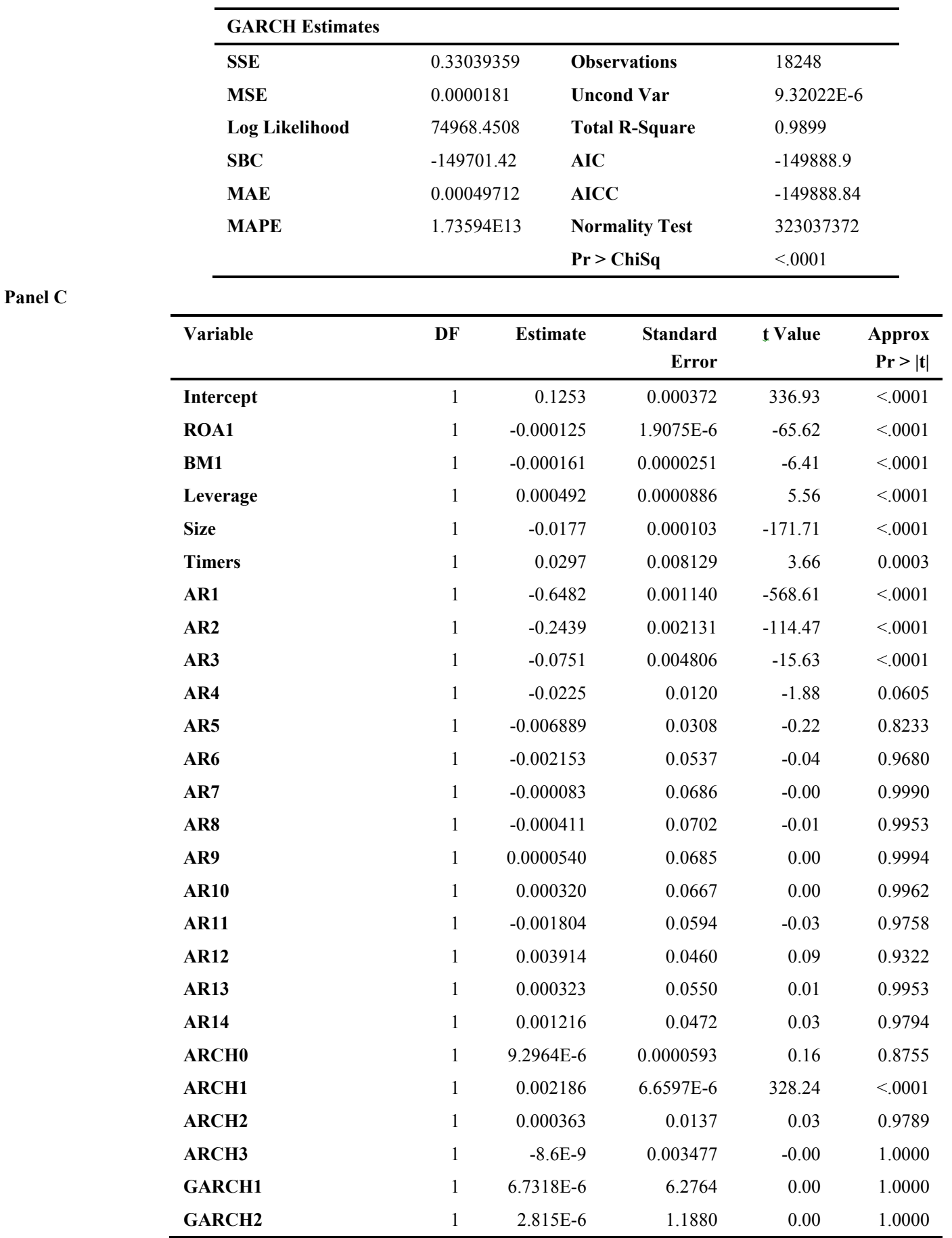

\section{Summary and Concluding Remarks}

Some IPOs companies' cross-list their shares in a host market, while that host market is up, whereas other IPOs companies cross-list their shares regardless of market conditions. The IPOs literature reports that IPOs companies who cross-list in foreign market are doing so to signal their positive prospects; however, those companies achieve negative abnormal returns after their IPOs. I used the $\mathrm{S} \& \mathrm{P}_{500}$ market index to condition for the host market condition and used the same market index to estimate the abnormal returns. I found that some IPOs companies that cross-list while the U.S. market (host market) is up, these companies achieve significant negative abnormal returns while others who cross-list their IPOs while the U.S. market (host market) is down, these companies achieve significant positive abnormal returns. If the firms that cross-list their IPOs shares while the U.S. market (host market) is up and 
achieve significant negative abnormal returns, then these companies are timing the market while others who cross-list their IPOs shares while the market is down they do not time the market.

Further, this paper focused on discovering any further evidence that can prove some companies do time the market. The discretionary accruals research reports if companies have a high degree of discretionary accruals, then those companies engage in earnings management. I built dummy variable DTIMERS that takes the value of one if the companies time the market and zero if they do not. I ran multiple regression models on an independent variable that is discretionary accruals using the most up to date research to confirm my analysis.

The paper used a wide variety of parametric and non-parametric tests and a diagnostic regression analysis adjusting for heteroscedasticity and autocorrelation. The evidence shows the companies that time the market has a positive and significant contribution to discretionary accruals, which means that those companies engage in earnings management and that may explain why those companies achieve significant negative abnormal returns after they cross-list.

This study makes a valuable contribution to the literature by highlighting the relationship between the IPOs cross-listing decision and the host market condition, post-listing abnormal returns, and the relation to earnings management. Researchers of cross-listing must take into consideration all those factors, investors must not buy shares of IPOs cross-listing companies without conducting due diligence, and financial analysts must not issue a recommendation to buy an IPO firm that cross-lists unless they have examined the timing of IPOs cross-listing and if there is any sign of earnings management involved.

This study leaves open opportunity for additional research to answer questions such as does cross-listing create value for market timers or non-market timers, and does the market generally overreact to cross-listing, regardless of whether the company times the market or not.

\section{References}

Ahmad-Zaluki, Nurwati A. (2008). Universiti Utara Malaysia, Malaysia Post-IPO Operating Performance and costs and ownership structure", Journal of Financial Economics, V. 3, No. 4, pp. 305-360.

Anand, A., F. Milne, \& L. Purda. (2006). Voluntary adoption of corporate governance mechanisms. Working paper no. 1112. Queen's Economics Department. [Online] Available: http://ssrn.com/abstract $=921450$.

B Baltagi. (2008). Econometric Analysis of Panel Data. 4th edition Wiley Chichester 2008.

Bailey, W., G. A. Karolyi, \& C. Salva. (2006). The economic consequences of increased disclosure: Evidence from international cross-listings. Journal of Financial Economics. 81(1):175-213. http://dx.doi.org/10.1016/j.jfineco.2005.06.002

Ball, Ray \& Lakshmanan Shivakumar. (2006). "Role of accruals in asymmetrically timely gain and loss recognition", Journal of Accounting Research. 44(2), 207-242. http://dx.doi.org/10.1111/j.1475-679X.2006.00198.x

Barth, M., \& G. Clinch. (1996). International accounting differences and their relation to share prices: Evidence from U.K., Australian, and Canadian firms. Contemporary Accounting Research. 13:135-170. http://dx.doi.org/10.1111/j.1911-3846.1996.tb00495.x

Barth, M.E., D.P. Cram, \& K.K. Nelson. (2001). 'Accruals and the Prediction of Future Cash Flows', Accounting Review, Vol. 76, pp. 27-58. http://dx.doi.org/10.2308/accr.2001.76.1.27

Biddle, G., \& S. Saudagaran. (1992). Foreign stock listing: Benefits, costs, and the accounting policy dilemma. Accounting Horizons. 5:69-80.

Bollerslev, T. (1986). Generalized autoregressive conditional heteroscedasticity. Journal of Econometrics. 51:307-27. http://dx.doi.org/10.1016/0304-4076(86)90063-1

Bollerslev, T. (1987). A conditional heteroscedastic time series model for speculative prices and rates of return. Review of Economics and Statistics. 69:542-47. http://dx.doi.org/10.2307/1925546

Bollerslev, T., R. F. Engle, \& D. B. Nelson. (1994). ARCH models, in Handbook of econometrics, Vol. 4, R. F. Engle and D. McFadden, eds. Amsterdam: North-Holland, 2959-3038.

Brav, A., Geczy, C., \& Gompers, P. (2000). Is abnormal performance following equity? Journal of Financial Economics, 56(2): 209-249. http://dx.doi.org/10.1016/S0304-405X(00)00040-4

Breusch, T.S. \& AR. Pagan. (1979). a simple test for heteroscedasticity and random coefficient variation, Econometrica. 47, 1287- 1294. http://dx.doi.org/10.2307/1911963

Bruner R, Chaplinsky S, Ramchand L. (2004). U.S.-bound IPOs: issue costs and selective entry. Financial Management. 33:39-60. 
Carow, K., S. Cox, \& D. Roden. (2006). the role of insider influence in mutual-to-stock conversions, Journal of Money, Credit, and Banking, forthcoming.

Carter, R. B., Dark, F. H., \& Singh, A. K. (1998). Underwriter reputation, initial returns, performance of IPO stocks. The Journal of Finance, 53(1), 285-311. http://dx.doi.org/10.1111/0022-1082.104624

Cheung CS, Lee J. (1995). Disclosure environment and listing on foreign stock exchanges. $J$ Bank Finance 19:347-362. http://dx.doi.org/10.1016/0378-4266(94)00092-H

Clarke, J., Dunbar, C., Kahle, K. (2001). Long-run performance and insider trading in completed vs. canceled seasoned equity offerings. Journal of Financial Quantitative Analysis 36, 415-430. http://dx.doi.org/10.2307/2676218

Clarke, J., Dunbar, C., Kahle, K. (2004). Long-run performance of secondary equity issues: a direct test of the windows of opportunity hypothesis. Journal of Business 77, 575-603. http://dx.doi.org/10.1086/386531

Cochrane, D. \& G.H. Orcutt. (1949). Application of least squares regression to relationships containing auto correlated error terms, Journal of the American Statistical Association 44, 32-61.

Daniel Kahneman, Jack L. Knetsch, Richard H. Thaler Anomalies. (1991). The Endowment Effect, Loss Aversion, and Status Quo Bias. the Journal of Economic Perspectives, 5(1), pp. 193-206, winter 1991.

Daniel, K.D. and Titman, S. (1999). "Market efficiency in an irrational world", Financial Analysts Journal, Vol. 55, pp. 28-40. http://dx.doi.org/10.2469/faj.v55.n6.2312

Daniel, K.D., Hirshleifer, D., \& Subrahmanyam, A. (1998). “Investor psychology and security Market under- and overreactions", Journal of Finance, Vol. 53, pp. 1839-85. http://dx.doi.org/10.1111/0022-1082.00077

Dechow, P. \& D. Skinner. (2000). "Earnings Management: Reconciling the Views of Accounting Academics, Practitioners, and Regulators." Accounting Horizons. 14 (2): 235-250. http://dx.doi.org/10.2308/acch.2000.14.2.235

Dechow, P. M., R. G. Sloan, \& A. P. Sweeney. (1995). Detecting earnings management. The Accounting Review. 70 : 193-225.

Dechow, P. M., R. G. Sloan, \& A. Sweeney. (1996). Causes and consequences of earnings manipulation: An analysis of firms subject to enforcement actions by the SEC. Contemporary Accounting Research. 13:1-36. http://dx.doi.org/10.1111/j.1911-3846.1996.tb00489.x

Dechow, P., \& D. Skinner. (2000). Earnings management: Reconciling the views of accounting academics, practitioners, and regulators. Accounting Horizons. 14(2):235-50. http://dx.doi.org/10.2308/acch.2000.14.2.235

Dechow, P., Dichev, I. (2002). The quality of accruals and earnings: The role of accrual estimation errors. The Accounting Review, 77, 35-59. http://dx.doi.org/10.2308/accr.2002.77.s-1.35

Dechow, P.M. (1994). 'Accounting Earnings and Cash Flows as Measures of Firm Performance: The Role of Accounting Accruals', Journal of Accounting and Economics.

Dechow, Patricia M., Richard G. Sloan, \& Amy Sweeney. (1996). Causes and consequences of earnings manipulation: An analysis of firms subject to enforcement actions by the SEC, Contemporary Accounting Research. 13, 1-36. http://dx.doi.org/10.1111/j.1911-3846.1996.tb00489.x

Desai, H., S. Rajgopal, \& M. Venkatachalam. (2004). Value-glamour and accruals mispricing: One anomaly or two? Accounting Review 79:355-85. http://dx.doi.org/10.2308/accr.2004.79.2.355

Doidge, C. (2004). U.S. cross-listings and the private benefit of control: evidence from dual-class firms. Journal of Financial Economics 72, 519-553. http://dx.doi.org/10.1016/S0304-405X(03)00208-3

Doidge, C., G. A. Karolyi, \& R. Stulz. (2004). Why are foreign companies that are listed in the U.S. worth more? Journal of Financial Economics. 71:205-38. http://dx.doi.org/10.1016/S0304-405X(03)00183-1

DuCharme, L., P. Malatesta, \& S. Sefcik. (2004). "Earnings management, stock issues, and shareholder lawsuits", Journal of Financial Economics. 71 (January), 27-49. http://dx.doi.org/10.1016/S0304-405X(03)00182-X

Erickson, M., Wang, S.W. (1999). Earnings management by acquiring firms in stock for stock mergers. Journal of Accounting and Economics. 27(2), 149-176. http://dx.doi.org/10.1016/S0165-4101(99)00008-7

Fuerst, O. (1998). A theoretical analysis of the investor protection regulations argument for global listing of stocks. Working paper. Yale University.

Gompers, P. A., \& Lerner, J. (2003). The really long-run performance of Initial Public NASDAQ evidence. The Journal of Finance, 57(4), 1355-1392. http://dx.doi.org/10.1111/1540-6261.00570 
Gordian A. Ndubizu. (2007). Do Cross-Border Listing Firms Manage Earnings or Seize a Window of Opportunity? The Accounting Review: July 2007, Vol. 82, No. 42007 pp. 1009-1030. http://dx.doi.org/10.2308/accr.2007.82.4.1009

Healy, P. M., \& J. M. Wahlen. (1999). A review of the earnings management literature and its implications for standard setting. Accounting Horizons. 13(4):365-83. http://dx.doi.org/10.2308/acch.1999.13.4.365

Healy, P.M. (1985). 'The Effect of Bonus Schemes on Accounting Decisions', Journal of Accounting and Economics, Vol. 7, pp. 85-107. http://dx.doi.org/10.1016/0165-4101(85)90029-1

Hirshleifer, D., Hou, K., Teoh, S., Zhang Y. (2004). Do investors overvalue firms with bloated balance sheets? Journal of Accounting and Economics, 38, 297-331. http://dx.doi.org/10.1016/j.jacceco.2004.10.002

Jain, B.A., \& Kini, O. (1994). The post-issue operating performance of IPO firms. Journal of Finance, 49, pp.1699-1726. http://dx.doi.org/10.1111/j.1540-6261.1994.tb04778.x

Jensen, M. (1986). Agency costs of free cash flow, corporate finance, and takeovers. American Economic Review. 76, 323-329.

Jo, H. and Y. Kim. (2007). 'Disclosure Frequency and Earnings Management', Journal of Financial Economics. 84, 561-590. http://dx.doi.org/10.1016/j.jfineco.2006.03.007

Jones, J. (1991), 'Earnings Management during Import Relief Investigations', Journal of Accounting Research, Vol. 29, No. 2, pp. 193-228. http://dx.doi.org/10.2307/2491047

Kang, S., Sivaramakrishnan, K. (1995). Issues in testing earnings management and an instrumental variable approach. Journal of Accounting Research. 33 (2), 353 - 367. http://dx.doi.org/10.2307/2491492

Kim, K.A., Kitsabunnarat, P., \& Nofsinger, J.R. (2004). Ownership and operating performance in an emerging market: evidence from Thai IPO firms. Journal of Corporate Finance, 10, pp. 355-381. http://dx.doi.org/10.1016/S0929-1199(02)00019-6

Kothari, S, Leone, A, Wasley, C. 2005. Performance matched discretionary accrual measures. Journal of Accounting and Economics, 39, 163-197. http://dx.doi.org/10.1016/j.jacceco.2004.11.002

Kutsuna, K., Okamura, H., \& Cowling, M. (2002). Ownership structure pre- and post-IPOs and the operating performance of JASDAQ companies. Pacific-Basin Finance Journal, 10, pp. 163-181. http://dx.doi.org/10.1016/S0927-538X(01)00041-5

Lang, M. H., K. V. Lins, and D. P. Miller. (2003). ADRs, analysts, and accuracy: Does cross-listing in the United States improve a firm's information environment and increase market value? Journal of Accounting Research. 41:317-45. http://dx.doi.org/10.1111/1475-679X.00106

Lang, M., J. S. Raedy, \& W. Wilson. (2006). Earnings management and cross-listing: Are reconciled earnings comparable to U.S. earnings? Journal of Accounting and Economics. 42:255-83. http://dx.doi.org/10.1016/j.jacceco.2006.04.005

Lau, S., D. Diltz, \& V. Apilado. (1994). Valuation effects of international stock exchange listings. Journal of Banking and Finance. 18: 743-755. http://dx.doi.org/10.1016/0378-4266(93)00018-K

Lee, I. (1991). The impact of overseas listing on shareholder wealth: The case of London and Toronto stock exchanges. Journal of Business Finance and Accounting. 18:582-92. http://dx.doi.org/10.1111/j.1468-5957.1991.tb01124.x

Ljungqvist, A., \& Wilhelm, W. (2003). IPO pricing in the dot-com bubble, Journal of Finance, Vol. 58, 723-752. http://dx.doi.org/10.1111/1540-6261.00543

Lowry, M., and K. Murphy. (2006). Executive stock options and underpricing, Journal of Financial Economics. 85 (2007) 39-65. http://dx.doi.org/10.1016/j.jfineco.2006.05.006

McLeod, A. I. \& W. K. Li. (1983). Diagnostic checking ARMA (Autoregressive moving average model) time-series models using squared-residual autocorrelations, Journal of Time-Series Analysis, 4, 269-273. http://dx.doi.org/10.1111/j.1467-9892.1983.tb00373.x

McNichols, M.F. (2002). 'Discussion: The Quality of Accruals and Earnings: The Role of Accruals Estimation Errors', Accounting Review, Vol. 77 (Supplement), pp. 61 -69. http://dx.doi.org/10.2308/accr.2002.77.s-1.61

Merjos, A. (1963). Like money in the bank: big board listing, the record suggests it is a valuable asset. Barron's. July 8,9 , and 13.

Merjos, A. (1962). Going on the big board: Stocks act better before listing than right afterward. Barron's. January 29, 5 and 14. 
MedihaMezhoud \& Adel Aoubaker. (2012). determination of the window to return to the equilibrium after the listing period, International Journal of Multidisciplinary Sciences and Engineering, Vol.3, No. 8 August 2012.

M. Fadl. (2013). Is there a post listing anomaly for IPOs Overseas Listings? Asian Journal of Empirical Research, Vol.3(9), 1131-1155.

Mikkelson, W.H., Partch, M.M., \& Shah, K. (1997). Ownership and operating performance of companies that go public. Journal of Financial Economics, 44, pp. 281-307. http://dx.doi.org/10.1016/S0304-405X(97)00006-8

Pagano, Marco, Ailsa A. Röell, \& Josef Zechner. (2002). The Geography of Equity Listing: Why Do Companies List Abroad? Journal of Finance, 57 (6), December. http://dx.doi.org/10.1111/1540-6261.00509

Pincus, M., S. Rajgopal, \& M. Venkatachalam. (2007). the accrual anomaly: International evidence, The Accounting Review. 82, 169-203. http://dx.doi.org/10.2308/accr.2007.82.1.169

Reese, W. A. J., \& M. S. Weisbach. (2002). Protection of minority shareholder interests, cross-listings in the United States, and subsequent equity offerings. Journal of Financial Economics. 66:65-104. http://dx.doi.org/10.1016/S0304-405X(02)00151-4

Ritter, Jay. (1984). "The 'Hot Issue' Market of 1980," The Journal of Business, Vol. 57, No. 2 (April 1984), pp. 215-40. http://dx.doi.org/10.1086/296260

Roosenboom, P., Vander Goot, T., \& Mertens, G. (2003). Earnings management and initial public offerings: evidence from the Netherlands. International Journal of Accounting, 38, pp. 243-266. http://dx.doi.org/10.1016/S0020-7063(03)00048-7

Rothman, M. (1995). The international dual-listing of stocks and tests of capital market segmentation. Working paper. University of Chicago.

Sanger, Gary C, \& John J, McConnell. (1986). Stock exchange listing, firm value and security market efficiency: The impact of the NASDAQ, Journal of Financial and Quantitative Analysis. 21, 1-25. http://dx.doi.org/10.2307/2330987

S. Agarwal, C. Liu, S.G. Rhee. (2008). Investor demand for IPOs and aftermarket performance: Evidence from the Hong Kong stock market, Journal of International Financial Markets, Institutions \& Money, Vol.18, 176-190. http://dx.doi.org/10.1016/j.intfin.2006.09.001

Shivakumar, L. (2000). Do firms mislead investors by overstating earnings before seasoned equity offerings? Journal of Accounting and Economics. 29: 339-372. 1030.

Smith, Katherine, \& Sofianos. (1997). the impact of an NYSE listing on global trading of non-U.S stocks, NYSE working paper 97-02.

Teoh, S.H., Welch, I., \& Wong, T.J. (1998). Earnings management and the long-run market performance of initial public offerings. Journal of Finance, 53, pp. 1935-1974. http://dx.doi.org/10.1111/0022-1082.00079

Valero, M., H. W. Lee, \& N. Cai. (2009). Cross-listing pursuit of unseasoned foreign firms after going public in the U.S. Journal of Business Research. 62(8):797-804. http://dx.doi.org/10.1016/j.jbusres.2008.02.007

White. H. (1980). a heteroscedasticity-consistent covariance matrix estimator and a direct test for heteroscedasticity, Econometrica. 48, 817-838. http://dx.doi.org/10.2307/1912934

William Greene. (2003). "An Interpreting Estimated Parameters and Measuring Individual Heterogeneity in Random Coefficient Models," Working Papers 03-19, New York University.

\section{Notes}

Note 1. I used the S\&P500 as the benchmark index to estimate and calculate the abnormal returns.

Note 2. See the literature review for further elaboration on the subject.

Note 3. More discussion on this variable is found on the next page.

Note 4. More discussion on the equation can be found in the section on hypothesis development.

Note 5. See the section on previous research and hypothesis development. 